\title{
Plant Growth Regulator Sprays and Girdling: Potential Horticultural Techniques to Increase Fruit Retention and Yield of Longan (Dimocarpus longan Lour.) Trees in California
}

\author{
A Thesis \\ Presented to the Faculty of \\ California Polytechnic State University \\ San Luis Obispo
}

In Partial Fulfillment of the Requirements for the Degree

Master of Science in Agriculture with Specialization in Crop Science

By

Leila Anne Graves

June 2009 
(C)2009

Leila Anne Graves

ALL RIGHTS RESERVED 


\section{Approval Page}

Title: $\quad$ Plant Growth Regulator Sprays and Girdling: Potential Horticultural Techniques to Improve Fruit Retention and Yield of Longan (Dimocarpus longan Lour.) Trees in California

Author: Leila Anne Graves

Date Submitted: June 2009

Committee Chair: $\quad$ Dr. Lauren Garner

Committee Chair: Dr. Keith Patterson

Committee Chair: $\quad$ Dr. William Kellogg 


\begin{abstract}
Plant Growth Regulator Sprays and Girdling:

Potential Horticultural Techniques to

Increase Fruit Retention and Yield of Longan (Dimocarpus longan Lour.) Trees in California

Leila Graves
\end{abstract}

June 2009

The longan is a subtropical fruit tree whose popularity is growing quickly among American consumers, and thus, could become a lucrative niche market for California growers. Trees planted as part of an initial variety trial conducted in commercial California orchards are beginning to bear fruit. However, fruit retention and yields are low due to excessive abscission during early fruit set. Horticultural techniques, such as plant growth regulator (PGR) sprays and girdling, often increase fruit retention and yield of fruit tree crops, though effects are typically dependent on treatment timing and PGR concentration. The objective of this study was to identify PGR and girdling techniques that result in increased longan fruit retention. The experiment was conducted in a commercial orchard using a randomized complete block design with whole-tree experimental units and five replications per treatment. Treatments included foliar applications of two synthetic auxins, 1-naphthaleneacetic acid (NAA) at 20, 60, or 100 ppm or 2,4-dichlorophenoxyacetic acid (2,4-D) at 5, 25, or 45 ppm, each applied during early or late fruit set. Girdling was also conducted at early or late fruit set, for a total of 15 treatments, including an untreated control. Factors examined at harvest included fruit number and mass per inflorescence and individual fruit mass and diameter. During the on-crop year, a significant increase in the number and mass of fruit per inflorescence was observed in response to $25 \mathrm{ppm}$ 2,4-D applied at late fruit set, as compared to the control. Despite this increase in fruit number, 
$25 \mathrm{ppm}$ 2,4-D applied at late fruit set did not result in decreased diameter and mass of individual fruit. Late fruit set applications of $25 \mathrm{ppm}$ 2,4-D appear to mitigate the effects of alternate bearing in the off-crop year. Fruit abscission during early and/or late fruit set decreased in response to $5 \mathrm{ppm}$ 2,4-D at early fruit set, 25 or $45 \mathrm{ppm}$ 2,4-D at early or late fruit set, or 100 ppm NAA at early fruit set. Fruit loss occurred as a result of Santa Ana winds during both growing seasons. Neither leaf nor fruit nutrient concentrations of treated trees were significantly different from that of untreated controls. Results indicate that properly-timed PGR applications have the potential to be used commercially to increase yield and profit to longan growers in California. 


\section{Acknowledgements}

I want to thank my graduate committee members, Dr. Lauren Garner (Chair), Dr. Keith Patterson, and Dr. William Kellogg for their support through this process. Thank you Dr. Lauren Garner for all the advice and support as well as providing the funding for my project.

Thank you to my family for the financial help and my friends for the moral support. Special thanks to my mother, Luzette Graves, for her assistance throughout this process and to my father, Achille Ango, for his moral support. Thank you, also to friends Evin Lambert, Ryan Perry, Bridey Root, Tiffany Tchouboukjian, Amanda Hallows, Maria Murietta, and Chris Phippen for their assistance with this project and moral support.

I would also like to thank Dr. Mark Gaskill, his wife, Judy Gaskill, and Ben Faber for their collaboration on this project. 


\section{Table of Contents}

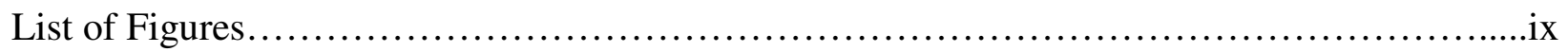

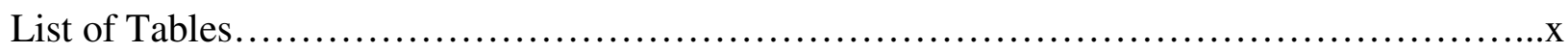

Chapters

1. Introduction

Literature Review.............................................................

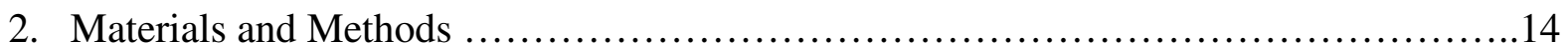

3. Results and Discussion................................................... 18

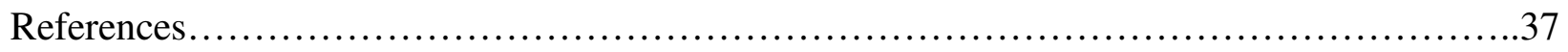

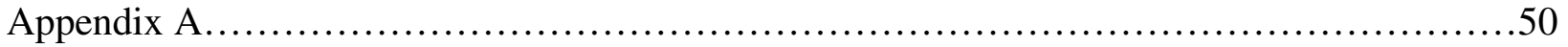




\section{List of Figures}

Fig. 1. Longan field site with Eucalyptus windbreak..................................14

Fig. 2. Vaca girdling knife used to girdle longan scaffold branches........................15

Fig. 3. Number of fruit per inflorescence during the 2008 growing season, including early fruit set (EFS), late fruit set (LFS), and during the Santa Ana winds...................23

Fig. 4. Longan fruit diameter during the 2008 growing season............................24 


\section{List of Tables}

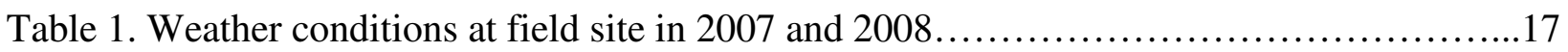

Table 2. The effect of girdling applied at early and late fruit set on the number of longan fruit per inflorescence, fruit mass per inflorescence, fruit mass, and fruit diameter...........19

Table 3. The effect of NAA applied at early or late fruit set on the number of longan fruit per inflorescence, fruit mass per inflorescence, longan fruit mass, and fruit diameter......20

Table 4. The effect of 2,4-D applied at early or late fruit set on the number of longan fruit per inflorescence, fruit mass per inflorescence, fruit mass, and fruit diameter.............21

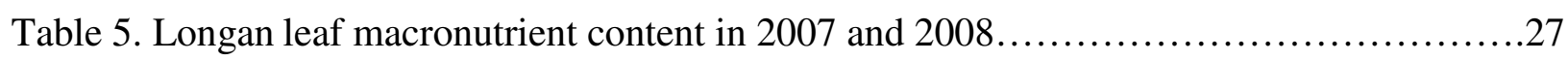

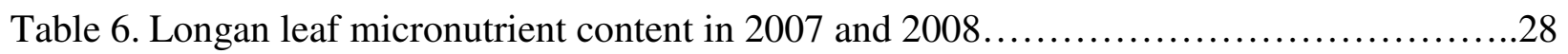

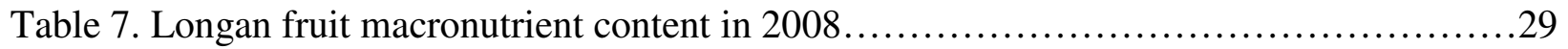

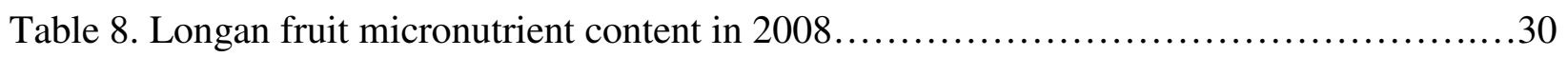

Table A1. Fruit macronutrient content at 2007 harvest.................................50

Table A2. Fruit micronutrient content at 2007 harvest......................................50 


\section{Chapter One}

Introduction

\section{Origin, History, and Value}

The longan, Dimocarpus longan Lour., is a subtropical evergreen tree (Subhadrabandhu and Stern, 2005) producing one of the largest agricultural commodities from the Sapindaceae family, second to litchi, Litchi chinensis Sonn (Huang et al., 2005). The longan is indigenous to southern China, Myanmar, and possibly southwest India and Sri Lanka (Tindall, 1994) and wild longan trees that produce small, unmarketable fruit still grow throughout these areas (Huang et al., 2005). Morphological studies of longan pollen suggest that the longan's center of origin is the Yunnan Province of southern China (Ke et al., 1994).

Detailed agricultural practices of longan production in China are on record as early as $116 \mathrm{BC}$ (Huang et al., 2005). It was not until the 1800's that longans were grown commercially outside of China. By the end of that century, the crop was being cultivated in Thailand, India, Sri Lanka, Myanmar, the Philippines, Cuba, the West Indies, Madagascar, and Australia (Huang et al., 2005). Longans were brought to Hawaii and Florida within the last 100 years (Menzel et al., 1989).

The litchi and longan are economically important to China, the countries of Southeast Asia, and to a lesser extent, India, and Sri Lanka (Huang et al., 2005). The majority of production occurs in China and Thailand. The largest longan industry is in China, with 937,500 t produced on 410,000 ha in 2008 (United States Department of Agriculture [USDA], 2008a). In 2007, cultivation of 150,240 ha of longan in Thailand resulted in the production of 495,000 $t$ of longan fruit (Office 
of Agricultural Economics, 2009). Though longans have been grown in Australia for more than 100 years (Huang et al., 2005), the majority of plantings were established within the past 15 years and yield 300 to $1000 \mathrm{t}$ (Nicholls, 2001) on approximately 200 ha (Food and Agriculture Organization [FAO], 2000). Production of longan in the United States is limited to Florida and Hawaii, with commercial orchards typically less than 20 years old (FAO, 2000). Cultivation of longan fruit in Florida is estimated to occur on 111 ha, yielding 2.1 billion $\mathrm{kg}$ and worth nearly \$9 million (Florida Agricultural Market Research Center, 2009). Less than 5\% of United States' cultivation occurs in Hawaii, with $119,295 \mathrm{~kg}$ produced on 65 ha for a farm gate value of $\$ 784,000$ (USDA, 2008b). Commercial production of longans in California is limited to experimental plots (Ventura County Cooperative Extension, 2009). A better understanding of the specific cultural methods required for successful production of the longan as a California niche crop is needed.

\section{Commercial Uses}

Longan fruit are typically marketed fresh, dried, or canned (Huang et al., 2005). Fresh longan fruit have a shelf-life of 2 to 4 weeks, provided they are stored at the appropriate temperature (Lin et al., 2001). Bruhn (2002) stated that chilling injury can occur at 5 to $15^{\circ} \mathrm{C}$ but Thompson (2002) asserted that storage and transportation temperatures between 0 to $2^{\circ} \mathrm{C}$ with $85 \%$ to $95 \%$ RH are optimal for preventing postharvest injury. Heat injury occurs when longans are stored at temperatures above $40^{\circ} \mathrm{C}$ (Bruhn, 2002). Irradiation, heat, controlled atmosphere conditioning, and/or pesticides are used to inhibit the growth of disease-causing organisms, including bacteria, yeasts, and fungi, known to result in the postharvest decay of longans (Holcroft et al., 2005). 
Sulfur dioxide treatments are used to prevent decay of longan fruit, in addition to preventing browning of the pericarp (Han et al., 2001).

Originally, longans and litchis were processed by drying, a method developed in China (Huang et al., 2005). Consumption of dried fruit is largely limited to Southeast Asia but future markets for dried longans are thought to exist in Europe and North America (Huang et al., 2005). Published studies of drying methods have focused primarily on litchis, though longans are processed by similar methods. The traditional method for the drying of litchi fruit is to place them in the sun for 30 to $40 \mathrm{~d}$ with fruit separated from the panicles for the last 10 to $20 \mathrm{~d}$ (Zee et al., 1998). However, drying in the sun results in highly variable quality; oven-drying under controlled temperatures is currently the preferred method (Huang et al., 2005). To maintain quality, dried litchis are washed in boiling water, fumigated with sulfur dioxide, dipped in hydrochloric acid, and rinsed in tap water (Galán and Menini, 1989).

A small percentage of longans are canned. This industry exists primarily in China, Taiwan, Vietnam, and Thailand (Huang et al., 2005). Longans are high in sugar, thus making it possible to can them in their own juice (Zee et al., 1998). Additional processing methods include freezing and the production of juice, wine, ice cream, preserves, and yoghurt (Huang et al., 2005).

\section{Flower and Fruit Development}

Longan flowers have not been studied extensively, though they are described as being botanically similar to litchi flowers (Davenport and Stern, 2005). Longan and litchi both have three flower types, male 1 (M1), female (F), and male 2 (M2), that are morphologically and 
functionally different from one another (reviewed in Davenport and Stern, 2005). All flowers are yellow-brown with five small petals. M1 flowers have eight hairy stamens with two-lobed anthers. The pistil contains two ovules that are not fully developed, thus making the flower functionally male. The F flower has a bifurcated stigma and an ovary with two carpels, each containing a single ovule. Typically only one of the locules of the longan ovary develops as the fruit matures, though doubles can occur. F flowers are functionally female, having anthers that typically do not contain viable pollen or dehisce. M2 flowers have stamen similar to those of M1 flowers but the pistil includes two functional ovules. M2 flowers are functionally male because the lobes of the stigma do not separate, thus preventing pollination. All three flower types have functional nectar discs and honeybees (Apis spp.) are required for successful pollination (Davenport and Stern, 2005).

Longan flowers are borne on determinate inflorescences up to $30 \mathrm{~cm}$ in length (Davenport and Stern, 2005). All three flower types are present on each inflorescence and open sequentially; M1 flowers open first, followed by F flowers, with M2 flowers opening last (Davenport and Stern, 2005; Zee et al., 1998). Each inflorescence produces approximately 300 to 400 flowers (Stern, 2005). Within an individual inflorescence, there is little overlap between flower types (Davenport and Stern, 2005). However, pollination of F flowers is possible because the rate of development of flowers and inflorescences varies both within and between trees (Davenport and Stern, 2005). The position of litchi flowers within an inflorescence and the sequence of flower openings are similar to that of longan (Robbertse et al., 1995). Though the ratio of female to male longan flowers has not been studied extensively, the sex ratio of litchi flowers varies greatly within the inflorescence and at the whole-tree level, as well as with cultivar, geographic 
location, and environmental conditions (Davenport and Stern, 2005). Flowering lasts for approximately 1 month in longan (Subhadrabandhu and Yapwattanphun, 2001) and litchi (Davenport and Stern, 2005).

Alternative litchi flowering patterns have been reported in which the M1 flowers are absent. F flowers open first, followed by M2 flowers. This pattern of flowering has been associated with tree age, a lack of flowering in previous seasons, and girdling (Davenport and Stern, 2005). Additionally, if flowering is initially unsuccessful, a second floral flush with only F and M2 flowers might be produced; inflorescences of this second flush often have a higher percent fruit set than that seen under typical, early-season growing conditions (Mustard et al., 1953).

The longan fruit is a drupe (Subhadrabandhu and Stern, 2005) with a leathery pericarp and a single aril that typically contains one seed (Stern, 2005). Investigations into the growth of longan fruit conducted on several cultivars have been reviewed by Stern (2005). Fruit growth occurs over 140 to $170 \mathrm{~d}$ and follows a sigmoidal pattern. At the end of a lag phase of approximately 50 $\mathrm{d}$, fruit mass is composed primarily of peel, pericarp, and seed. The aril then grows rapidly for approximately $60 \mathrm{~d}$, stretching the peel and pericarp; seed maturation also occurs during this time. Aril growth continues for the next 30 to $60 \mathrm{~d}$. Final fruit size ranges from 5 to $20 \mathrm{~g}$ in mass and from 1.2 to $3.0 \mathrm{~cm}$ in diameter.

Fruit abscission rates of both longan and litchi are high, with only $20 \%$ and 5\% of flowers setting fruit, respectively (Stern, 2005). The majority of longan fruit abscise within 3 weeks of fertilization, with a second, smaller period of fruit abscission 1 to 2 months before harvest (Zee 
et al., 1998). Litchi fruit abscission is also characterized by heavy, early fruit abscission and limited preharvest drop; this pattern has been described in detail by researchers working in several countries (Chadha and Rajpoot, 1969; Chang, 1961; Joubert, 1986; Mustard et al., 1953; Stern et al., 1995). Early fruit abscission of litchi occurs in two waves (Stern et al., 1995; Yuan and Huang, 1988). Fruit abscised in the first wave have unfertilized embryos; without successful fertilization, retention of these fruit is not possible. The second wave of litchi fruit that abscise during early fruit abscission contain successfully fertilized embryos.

Environmental Factors and Cultural Methods Affecting Longan and Litchi Reproductive Growth $\underline{\text { and Development }}$

Floral initiation and inflorescence and fruit development of longan and litchi are controlled by light intensity and temperature. Growth and development can also be manipulated by cultural methods such as girdling and foliar applications of plant growth regulators (PGRs). Both longan and litchi are described as having comparable growing requirements and are produced using similar cultural methods but few published studies focusing solely on longans are available.

\section{Light}

Though longan and litchi are day neutral with respect to flowering (Davenport and Stern, 2005), the reproductive growth and development of both species are influenced by light intensity. Leaves located immediately below longan and litchi inflorescences are the source of most of the carbohydrates required for fruit growth, though some carbohydrates are synthesized from sugar stored translocation from other branches (Menzel, 2005). If $\mathrm{CO}_{2}$ fixation decreases in these leaves, assimilates can be drawn from more distant sources (Menzel, 2005). Decreased light 
intensity can reduce photosynthetic productivity of source leaves and reduce fruit production (Menzel, 2005). The effects of reduced light intensity on shoot extension and leaf expansion were evaluated during a study of litchi seedlings (Hieke et al., 2002). Seedlings were grown in

full sun with a photosynthetic photon flux density (PPFD) of $1080 \mu \mathrm{molm}^{-2} \mathrm{~s}^{-1}$ or were exposed to artificial shade treatments of $20 \%, 40 \%$, or $70 \%$ sun exposure with maximum PPFDs of 500, 900 , or $1400 \mu \mathrm{molm}^{-2} \mathrm{~s}^{-1}$, respectively. Seedlings grown in maximum shade were significantly shorter and had approximately half the total mass of those grown in full sun.

During a series of experiments, Yuan and Huang (1988) demonstrated that exposure of fruiting branches to light is critical during early development of litchi fruit. Individual branches were shaded to decrease light interception by $90 \%$. Shading for $7 \mathrm{~d}$ at full bloom or 3 weeks after full bloom decreased fruit production by $76 \%$ or $64 \%$, respectively as compared to the control branches exposed to full sun (Yuan and Huang, 1988). Thus, light intensity is a limiting factor in litchi fruit production, possibly reducing yields in climates characterized by overcast periods during bloom (Menzel, 2005).

\section{Temperature}

The longan and litchi are dependent on temperatures above $10^{\circ} \mathrm{C}$ for proper vegetative and reproductive growth and development (Menzel and Paxton, 1985). Both species are frost sensitive; vegetative growth is damaged at air temperatures between 0 and $2^{\circ} \mathrm{C}$ and the trunk and tree will die if the air temperature drops to -2 to $-4.4^{\circ} \mathrm{C}$ or less for any extended period (Huang et al., 2005; Morton, 1987; Zee et al., 1998). 
Above $10^{\circ} \mathrm{C}$, the rate of vegetative growth of litchi increases rapidly with moderate increases in temperature. Menzel and Paxton (1985) grew litchi seedlings under cool or warm day/night temperature regimes $\left(15 / 10^{\circ} \mathrm{C}\right.$ or $25 / 20^{\circ} \mathrm{C}$, respectively) and then increased temperatures to $20 / 15^{\circ} \mathrm{C}$ or $30 / 25^{\circ} \mathrm{C}$, respectively. This $5^{\circ} \mathrm{C}$ increase in temperature resulted in a 4.5 -fold increase in leaf and stem dry weights and a 2.5 -fold increase in root dry weight under both temperature regimes. Optimal shoot production has been reported to occur at temperatures between 20 and $35^{\circ} \mathrm{C}$, with optimal leaf elongation at $35^{\circ} \mathrm{C}$ (Batten and Lahav, 1994).

Reproductive growth of longan and litchi is also affected by temperature. Both species need low temperatures for flowering. Litchi flower initiation requires temperatures of 14 to $20^{\circ} \mathrm{C}$ for 6 to 8 weeks (Menzel and McConchie, 1997; Nakata and Watanabe, 1966; Zee et al., 1998). Though specific chill requirements for longan flower initiation appear to be unpublished, the species is described as requiring less chill than litchis (Zee et al., 1998). Temperature also affects the sex ratio of male to female flowers, with the production of female flowers being favored by lower temperatures (Menzel and Simpson, 1988).

In addition to floral initiation, other aspects of litchi reproductive growth are also affected by temperature. In a study of two litchi cultivars, Stern and Gazit (1998) found that ovule and pollen development and in vivo pollen germination were typically successful at temperatures between 17 and $27^{\circ} \mathrm{C}$, though temperature optima were cultivar dependent (Stern and Gazit, 1998). Temperatures of $32^{\circ} \mathrm{C}$ can result in sterile pollen and ovules of 'Floridian' litchi (Stern and Gazit, 1998). High temperatures are also reported to result in increased fruit abscission after fruit set (Menzel and McConchie, 1997). 


\section{Girdling}

Girdling, ringing, and cincturing are horticultural techniques that temporarily limit movement of sugar and other substances by removing or restricting the phloem (reviewed in Goren et al., 2004). Girdling is used as a common method of improving fruit yield by increasing flower production and/or enhancing fruit set (reviewed in Goren et al., 2004).

Litchi branches can be girdled in autumn to increase flowering in the spring. In China, autumn girdling has been shown to significantly increase flowering, fruit set, and yield in 'Nuomici' litchi by more than $50 \%$ as compared to the control ( $\mathrm{Li}$ and Xiao, 2001). Girding has also been used to promote flowering under non-inductive temperatures. Young (1957) found that the yield of 'Brewster' litchi trees girdled in September in Florida was approximately double that of control trees. Later girdles (in October or November) were less effective at increasing yields than early girdles (Davenport and Stern, 2005). This is likely due to the fact that sufficient chill for floral induction occurred prior only to the later girdling treatments (Davenport and Stern, 2005). Girdling of longan trees has been used experimentally to promote flowering (Wu et al., 2000).

Girdling after flowering has also been utilized by Yuan and Huang (1988 and 1991) to study source-sink relationships of litchi. Fruit retention was increased in response to the girdling of fruiting branches of 'H-1224' (Yuan and Huang, 1988 and 1991). Menzel (2004) reported that girdling in Australia 1 month after fruit set increased yield of 'Tai So' litchi 3-fold as compared to the control. In the same experiment, girdling branches of 'Kwai May Pink' and 'Wai Chee' litchi increased yield by 35\% as compared to control branches (Menzel, 2004). No reports of using girdling after flowering to improve longan fruit set appear to have been published. 
Menzel (2004) has suggested that increases in litchi and longan production in response to girdling should be possible. However, commercial use of this technique on these crops is limited, possibly because lasting effects on the health of trees are unknown (Menzel, 2004). For example, girdling the same branch two years in a row is thought to be detrimental to litchi tree health (University of Hawaii, 2002).

Girdling results in changes in the allocation of assimilates within the tree. Root growth is decreased due to inhibition of the flow of sugars and auxin from leaves to roots (Lomax et al., 1995). The results of both field and laboratory experiments by Huang (2002) demonstrated that the transport of ${ }^{14} \mathrm{C}$-photosynthates to the roots was inhibited by shoot girdling of litchi. It was also reported that carbohydrate concentrations were higher in fruit on girdled litchi trees than on non-girdled trees. The author concluded that the increase in fruit set in response to girdling was a result of the elimination of fruit-root photosynthate competition during fruit set.

Girdled litchi trees often fail to produce M1 flowers (Nakata, 1956). This shift to a higher ratio of M2 to F flowers could explain, in part, why girdled litchi branches are more likely to set fruit. Increased rates of pollination and fertilization might occur because M2 flowers produce more pollen grains than M1 flowers (Stern, 1992 and Costés, 1988) and M2 pollen tubes are more likely to reach the embryo sac than M1 pollen tubes (Stern and Gazit, 1998). Other conditions resulting in the alternative flowering pattern in which only $\mathrm{M} 2$ and F flowers are produced can also promote increased fruit set (Mustard et al., 1953). 


\section{Manipulation of PGR Content}

Abscission is controlled by the interaction of endogenous PGRs (Burger, 2003). Though the final stages of abscission are controlled be ethylene, the vitality of the cells in the abscission zone is dependent on auxin (Burger, 2003). The sink strength of many fruit is also dependent on auxin content, which is particularly high in the seed (reviewed in Ozga and Reinecke, 2003). Developing fruit that have low auxin concentrations grow more slowly than those with higher auxin concentrations and are more likely to abscise (reviewed in Bangerth, 2000).

Litchi seeds produce auxin during the first months of fruit development (Ji et al., 1992) though seedless cultivars have low auxin concentrations as compared to seeded cultivars (Xiang et al., 1994). Litchi fruit that abscise in the second wave of abscission are characterized by a decline in the concentration of the endogenous auxin, indole-3acetic acid (IAA) (Stern et al., 1995). In one of the few published studies on longan PGR content, it was reported that auxin levels decrease during both the first and second waves of abscission of fruit set (Zhou et al., 1999).

PGRs are often applied exogenously to fruit trees to manipulate vegetative and reproductive growth in order to increase yields (Southwick, 2003). The second wave of litchi fruit abscission can be reduced by applications of synthetic auxin derivatives but proper timing, chemical structure, and application rates are critical for increasing marketable yields (Stern et al., 1995; Stern and Gazit, 1997; Stern and Gazit, 1999). The synthetic auxin, 2,4,5-trichlorophenoxyacetic acid (2,4,5-T) increases litchi fruit set at a relatively wide range of concentrations (35 to 100 ppm) but effectiveness is dependent on cultivar and timing of application (Prasad and Jauhari, 1963; Stern and Gazit, 1997; Stern et al., 2001; Xu, 1962). Treatments resulted in increased fruit 
set and mass if 2,4,5-T was applied during early fruit set (4 weeks after anthesis of $\mathrm{F}$ flowers), whereas treatments applied earlier failed to result in any increases (Stern et al., 2001). Mean fruit mass was reduced in response to higher concentrations or multiple spray applications (Xu, 1962). The use of 2,4,5-T in the United States was banned in 1979 upon discovery that it contains the highly toxic dioxin, 2,3,7,8-tetrachlorodibenzo-p-dioxin (TCCD) (Smith, 1979). Therefore, other synthetic auxins, such as 1-naphthaleneacetic acid (NAA) and 2,4-dichlorophenoxyacetic acid (2,4-D), are required in the United States for improving fruit set with PGR applications.

NAA is used commercially to influence fruit set, increase fruit size, and decrease preharvest drop of many fruit tree crops (Southwick, 2003). Applications of NAA have been used to inhibit litchi vegetative growth, resulting in increased floral induction, thereby increasing fruit production (Davenport and Stern, 2005). Effects on flowering and fruit development are minimal when NAA is applied to litchi trees during conditions that promote vegetative flushing (Mustard et al., 1956). Increased retention of developing litchi fruit can also be achieved with appropriately timed applications of NAA. When applied during early fruit set, $10 \mathrm{ppm}$ NAA resulted in a significant increase in fruit set as compared to untreated control trees (Yuan and Huang, 1991). Fruit set was further increased when branches were girdled prior to NAA applications (Yuan and Huang, 1988). Fruit retention of 'Purbi' litchi has also been reported to occur with applications of 10 ppm NAA during fruit set (Hoda et al., 1973). Applications of 10 to 100 ppm NAA applied at late fruit set to litchi resulted in a more than $70 \%$ increase in fruit set as compared to the controls (Prasad and Jauhari, 1963).

$\underline{2,4-\mathrm{D}}$ 
Properly timed applications of 2,4-D can be used to decrease mid- and late-season abscission of several fruit tree crops (Gianfagna, 1990). When applied a few weeks after petal fall, 2,4-D can be used to increase citrus fruit set (Coggins, 2003). For example, premature fruit drop in lemons can be prevented by applications of 25 ppm 2,4-D (Stewart and Hield, 1949). Applications of 15 ppm 2,4-D also result in increased litchi fruit set (Hoda et al., 1973); the most effective application time is 2 weeks after bloom (Huang, 2002).

Though the use of PGRs and girdling to improve litchi fruit set is well established, these techniques have not been researched or utilized effectively with longan. Taken together, these studies suggest that properly timed exogenous PGR applications or girdling could be used to manipulate the reproductive growth of longan, thereby increasing yields. Longan variety trials have been established in California, with the aim of marketing the fruit as a high-value niche crop but management techniques need to be developed for successful longan production in California on a commercial scale. The horticultural use of both exogenous PGRs and girdling provide two possible strategies for increasing fruit set. Therefore, the objective of this study is to identify PGR and girdling regimes to increase longan fruit retention, thereby increasing yield and profits for California growers. 


\section{Chapter Two}

Materials and Methods

\section{Field Site and Experimental Design}

This study was conducted during the growing seasons of 2007 and 2008, using bearing, eight year-old 'Kohala' longan trees in a commercial orchard in Somis, CA. (lat. $34^{\circ} 15^{\prime}$ N, long. $119^{\circ} 01^{\prime} \mathrm{W}$; elevation $\left.126 \mathrm{~m}\right)$. Trees were planted $4.5 \mathrm{~m}$ from trunk to trunk within and between rows in raised beds and irrigated with micro-sprinklers. The experiment was conducted using whole-tree experimental units in a randomized complete block design (RCBD) with five replications per treatment. Trees were blocked by row, which were orientated parallel to an adjacent Eucalyptus camaldulensis Dehn. windbreak (Fig. 1).

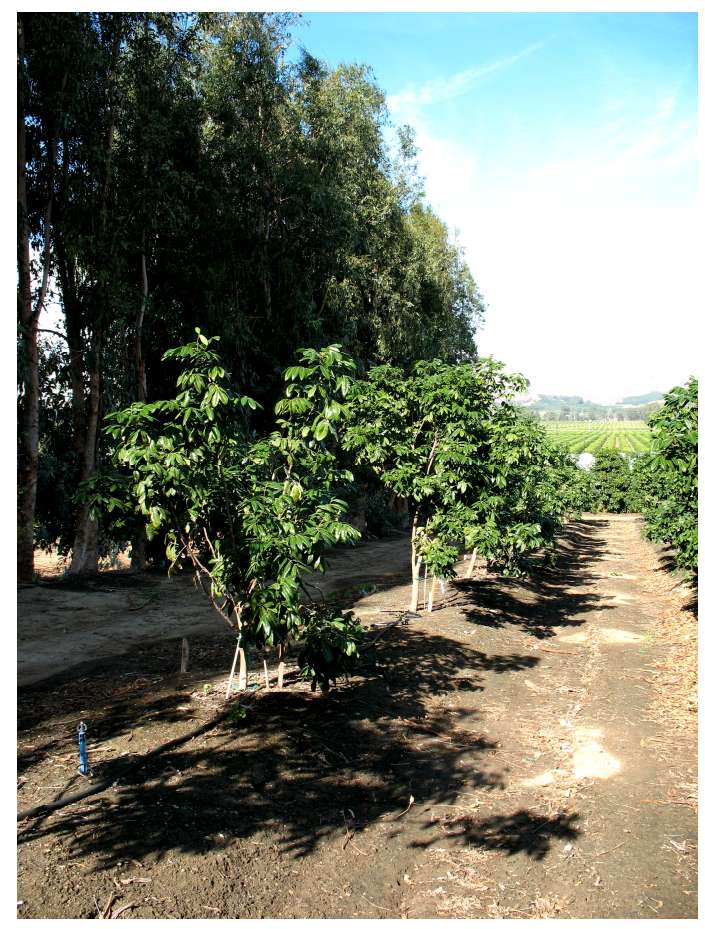

Fig. 1. Longan field site with Eucalyptus windbreak. 
Twelve foliar PRG treatments were utilized. Trees were sprayed with 2,4-D (Citrus Fix; AMVAC Chemical Corporation; Los Angeles, CA) or NAA (Fruitone; AMVAC Chemical Corporation) at one of three concentration rates $(5,25$ or $45 \mathrm{ppm}$ or 20,60 or $100 \mathrm{ppm}$, respectively). Two application times were used: early fruit set (23 July 2007 and 7 July 2008) or late fruit set (13 August 2007 and 1 August 2008), for a total of 12 PGR treatments. Girdling was accomplished with a Vaca girdling knife (Wenatchee, WA) that removed a $0.64 \mathrm{~cm}$ strip of bark from a scaffold branch of tree not sprayed with PGRs (Fig. 2). There were a total of 15 treatments, including an untreated control.

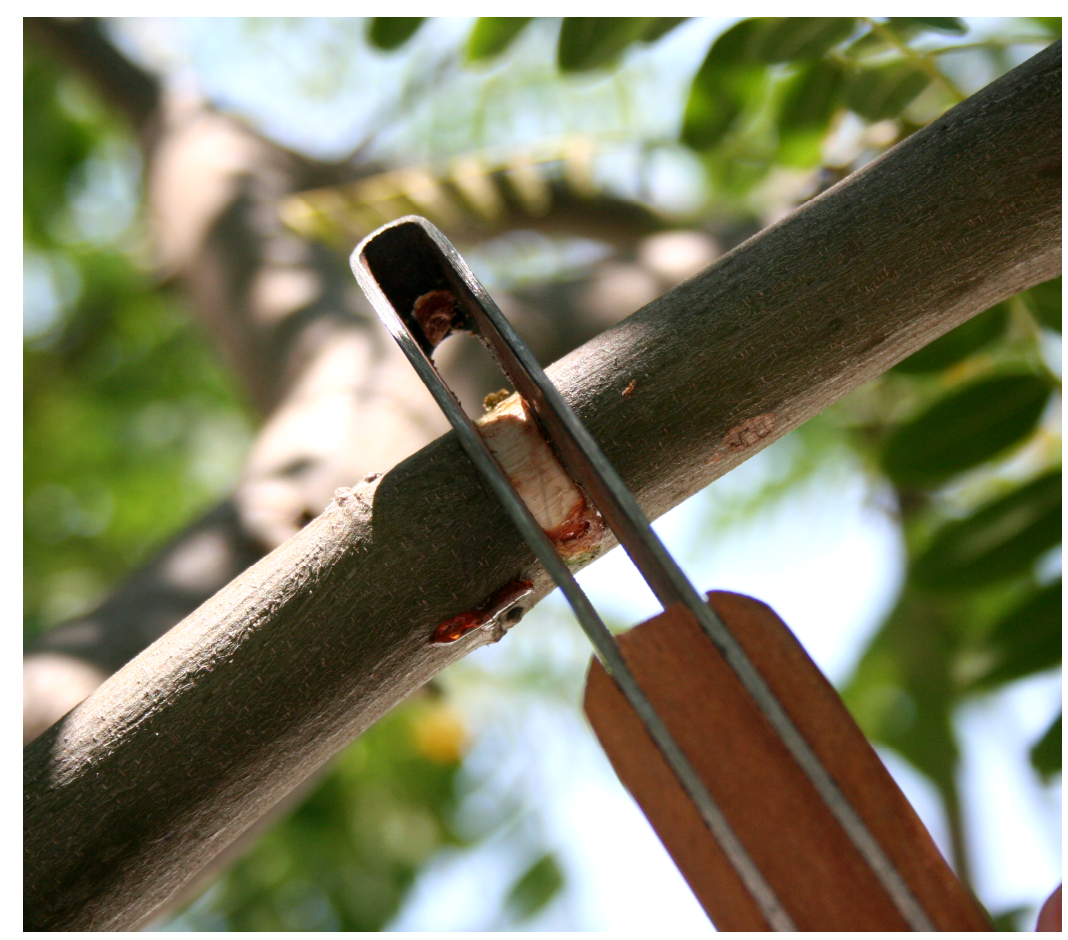

Fig. 2. Vaca girdling knife used to girdle longan scaffold branches. 


\section{$\underline{\text { Flowering, Fruit Set, and Yield }}$}

Longan reproductive development was measured quantitatively and qualitatively from bloom to final fruit collection of both years. During 2007, two branches with at least three inflorescences were subsampled on each tree to study fruit development before treatment application and at harvest. Data collected included fruit number and estimated diameter. In 2008, the trees appeared to be in an off-crop year and up to three inflorescences per tree were subsampled whenever available. Additional determinations of fruit number were made in September, October, and November of 2007 (control trees only). In 2008, inflorescences were counted on all study trees and the number and diameter of fruit on each subsampled branch were determined approximately monthly during set. At each data collection period, observations were also made to determine evidence of phytotoxicity and to verify that all the girdling cuts healed. At harvest, fruit from all subsampled branches were collected and measured to determine mass and diameter. Fruit set was determined by counting the number of fruit per inflorescence on each subsampled branch and diameter was determined using a caliper. During the 2008 harvest, fruit were also collected and measured from all nonsampled inflorescences of each study tree. In 2008, trees in the two blocks adjacent to the windbreak had low vigor and few inflorescences, resulting in numerous trees with $0 \%$ fruit set and/or no yield. Statistical analyses of 2008 yield data were, therefore, conducted using only three blocks.

\section{$\underline{\text { Tree Nutrient Status }}$}

Twenty hardened leaflets from each of two leaves were collected at a height of $1.5 \mathrm{~m}$ from branches distributed uniformly around each tree. Leaves were removed approximately 1 month before early fruit set (19 May 2007 and 26 June 2008) from non-flowering, terminal, spring 
vegetative growth. Spring leaf samples and fruit collected at harvest were dried in a forced-air oven at $87^{\circ} \mathrm{C}$ and sent to Fruit Growers Laboratory (Santa Paula, CA) for mineral nutrient analysis.

\section{$\underline{\text { Weather Conditions }}$}

Weather data was downloaded from the California Irrigation Management Information System (CIMIS) website (California Department of Water Resources, 2008). Daily wind speed, precipitation, solar radiation, and maximum, minimum, and average air temperatures were obtained from the closest coastal station, Camarillo \# 152 (lat. 34 $13^{\prime} \mathrm{N}$, long. 118 $58^{\prime} \mathrm{W}$; elevation $45.72 \mathrm{~m}$ ). There were no statistically significant differences between the two study years for any of these observed variables (Table 1). Wind gusts measurements for 2007 and 2008 were obtained from the National Oceanic and Atmospheric Administration station, Camarillo Airport \# 23136 (lat $34^{\circ} 22^{\prime} \mathrm{N}$, long. $119^{\circ} 08^{\prime} \mathrm{W}$; elevation: $83.5 \mathrm{~m}$ ) (NOAA, 2009).

Table 1. Weather conditions at field site in 2007 and 2008.

\begin{tabular}{llclccc}
\hline \hline & \multicolumn{5}{c}{ Temperature $\left({ }^{\circ} \mathrm{C}\right)$} & \multicolumn{2}{c}{ Precipitation $(\mathrm{mm})$} & RH $(\%)$ & Wind Speed $\left(\mathrm{m} \cdot \mathrm{s}^{-1}\right)$ \\
\cline { 2 - 7 } Year & Maximum & Minimum & Average & & & \\
\hline 2007 & 21.86 & 9.11 & 15.09 & 11.1 & 68.17 & 1.53 \\
2008 & 22.45 & 9.33 & 15.53 & 23.1 & 66.83 & 1.59 \\
\hline$P^{\mathrm{z}}$ & 0.16 & 0.47 & 0.09 & 0.16 & 0.40 & 0.33 \\
\hline
\end{tabular}

${ }^{\mathrm{z}}$ Probability value of paired $t$ test comparison of yearly means.

\section{$\underline{\text { Statistical analyses }}$}

Statistical analyses were conducted using Minitab (Minitab Inc., State College, PA). Treatment differences were detected by analysis of variance (ANOVA) and Dunnett's two-tailed $t$ tests at $\alpha$ $\leq 0.05$. Paired $t$ tests $(\alpha \leq 0.05)$ were used to compare yearly means. 


\section{Chapter Three}

\section{Results and Discussion}

\section{$\underline{\text { Results }}$}

None of the treatments resulted in phytotoxicity and all of the girdling wounds healed. Only a few significant differences were detected for any measured variables in either study year. In 2007 and 2008, girdling and NAA applied at early or late fruit set did not result in significant changes in number and mass of fruit per inflorescence as compared to the control (Tables 2 and 3). Individual fruit mass and diameter were also not significantly affected by girdling and NAA treatments in 2007 (Tables 2 and 3). Applications of 2,4-D at early fruit set did not result in significant differences in any of the measured variables as compared to the control (Table 4). A significantly higher number of fruit per inflorescence and fruit mass per inflorescence as compared to the control were observed in response to $25 \mathrm{ppm}$ 2,4-D applied at late fruit set in 2007 (Table 4). This effect was equivalent to a more than 2.5-fold increase in number of fruit per inflorescence and a nearly 3-fold increase in fruit mass per inflorescence. Late fruit set applications of $25 \mathrm{ppm}$ 2,4-D also resulted in significantly higher fruit diameter but did not significantly affect individual fruit mass (Table 4). No other 2,4-D applications resulted in significant differences in the measured variables as compared to the control in either year (Table 4), though in 2007, all treatments resulted in numerically larger number and mass of fruit per inflorescence as compared to the untreated control (Tables 2-4). 
Table 2. The effect of girdling applied at early and late fruit set on the number of longan fruit per inflorescence, fruit mass per inflorescence, fruit mass, and fruit diameter.

\begin{tabular}{|c|c|c|c|c|c|c|c|c|c|}
\hline Year & Treatment & $\begin{array}{c}\text { Fruit per } \\
\text { inflorescence } \\
\text { (no.) }\end{array}$ & $t$ tests $^{\mathrm{z}}$ & $\begin{array}{l}\text { Fruit mass per } \\
\text { inflorescence } \\
(\mathrm{g})\end{array}$ & $t$ tests & $\begin{array}{c}\text { Fruit mass } \\
(\mathrm{g})\end{array}$ & $t$ tests & $\begin{array}{l}\text { Fruit diameter } \\
(\mathrm{mm})\end{array}$ & $t$ tests \\
\hline 2007 & Untreated control & 9.88 & & 40.34 & & 4.13 & & 16.90 & \\
\hline 2007 & Girdled at early fruit set & 17.66 & NS & 68.32 & NS & 3.85 & NS & 18.33 & NS \\
\hline 2007 & Girdled at late fruit set & 10.84 & NS & 40.97 & NS & 4.17 & NS & 16.63 & NS \\
\hline 2008 & Untreated control & 8.43 & & 54.33 & & 6.51 & & 21.03 & \\
\hline 2008 & Girdled at early fruit set & 6.67 & NS & 45.86 & NS & 8.14 & NS & 20.88 & NS \\
\hline 2008 & Girdled at late fruit set & 9.69 & NS & 66.27 & NS & 6.38 & NS & 23.90 & NS \\
\hline
\end{tabular}

${ }^{\mathrm{z}}$ Mean separations within column for each year by Dunnett's $t$ tests, with NS as nonsignificant at $P=0.05$. 
Table 3. The effect of NAA applied at early or late fruit set on the number of longan fruit per inflorescence, fruit mass per inflorescence, fruit mass, and fruit diameter.

\begin{tabular}{|c|c|c|c|c|c|c|c|c|c|}
\hline Year & Treatment & $\begin{array}{c}\text { Fruit per } \\
\text { inflorescence } \\
\text { (no.) }\end{array}$ & $t$ tests $^{\mathrm{z}}$ & $\begin{array}{l}\text { Fruit mass per } \\
\text { inflorescence } \\
(\mathrm{g})\end{array}$ & $t$ tests & $\begin{array}{c}\text { Fruit mass } \\
(\mathrm{g})\end{array}$ & $t$ tests & $\begin{array}{l}\text { Fruit diameter } \\
(\mathrm{mm})\end{array}$ & $t$ tests \\
\hline 2007 & Untreated control & 9.88 & & 40.34 & & 4.13 & & 16.90 & \\
\hline 2007 & $\begin{array}{c}\text { NAA }(20 \mathrm{ppm}) \\
\text { early fruit set } \\
\text { late fruit set }\end{array}$ & $\begin{array}{l}11.09 \\
16.95\end{array}$ & $\begin{array}{l}\text { NS } \\
\text { NS }\end{array}$ & $\begin{array}{l}49.99 \\
66.48\end{array}$ & $\begin{array}{l}\text { NS } \\
\text { NS }\end{array}$ & $\begin{array}{l}4.34 \\
3.70\end{array}$ & $\begin{array}{l}\text { NS } \\
\text { NS }\end{array}$ & $\begin{array}{l}18.01 \\
16.93\end{array}$ & $\begin{array}{l}\text { NS } \\
\text { NS }\end{array}$ \\
\hline 2007 & $\begin{array}{c}\text { NAA }(60 \mathrm{ppm}) \\
\text { early fruit set } \\
\text { late fruit set }\end{array}$ & $\begin{array}{l}17.54 \\
13.75\end{array}$ & $\begin{array}{l}\text { NS } \\
\text { NS }\end{array}$ & $\begin{array}{l}82.92 \\
53.16\end{array}$ & $\begin{array}{l}\text { NS } \\
\text { NS }\end{array}$ & $\begin{array}{l}4.91 \\
3.71\end{array}$ & $\begin{array}{l}\text { NS } \\
\text { NS }\end{array}$ & $\begin{array}{l}16.85 \\
17.20\end{array}$ & $\begin{array}{l}\text { NS } \\
\text { NS }\end{array}$ \\
\hline 2007 & $\begin{array}{c}\text { NAA (100ppm) } \\
\text { early fruit set } \\
\text { late fruit set }\end{array}$ & $\begin{array}{l}16.92 \\
15.23\end{array}$ & $\begin{array}{l}\text { NS } \\
\text { NS }\end{array}$ & $\begin{array}{l}73.75 \\
56.06\end{array}$ & $\begin{array}{l}\text { NS } \\
\text { NS }\end{array}$ & $\begin{array}{l}4.00 \\
3.69\end{array}$ & $\begin{array}{l}\text { NS } \\
\text { NS }\end{array}$ & $\begin{array}{l}18.15 \\
17.26\end{array}$ & $\begin{array}{l}\text { NS } \\
\text { NS }\end{array}$ \\
\hline 2008 & Untreated control & 8.43 & & 54.33 & & 6.51 & & 21.03 & \\
\hline 2008 & $\begin{array}{c}\text { NAA }(20 \mathrm{ppm}) \\
\text { early fruit set } \\
\text { late fruit set }\end{array}$ & $\begin{array}{l}4.67 \\
7.31\end{array}$ & $\begin{array}{l}\text { NS } \\
\text { NS }\end{array}$ & $\begin{array}{l}43.34 \\
54.05\end{array}$ & $\begin{array}{l}\text { NS } \\
\text { NS }\end{array}$ & $\begin{array}{l}5.67 \\
3.78\end{array}$ & $\begin{array}{l}\text { NS } \\
\text { NS }\end{array}$ & $\begin{array}{l}23.08 \\
21.77\end{array}$ & $\begin{array}{l}\text { NS } \\
\text { NS }\end{array}$ \\
\hline 2008 & $\begin{array}{c}\text { NAA }(60 \mathrm{ppm}) \\
\text { early fruit set } \\
\text { late fruit set }\end{array}$ & $\begin{array}{l}8.61 \\
6.61\end{array}$ & $\begin{array}{l}\text { NS } \\
\text { NS }\end{array}$ & $\begin{array}{l}68.27 \\
30.03\end{array}$ & $\begin{array}{l}\text { NS } \\
\text { NS }\end{array}$ & $\begin{array}{l}7.92 \\
5.63\end{array}$ & $\begin{array}{l}\text { NS } \\
\text { NS }\end{array}$ & $\begin{array}{l}20.70 \\
23.42\end{array}$ & $\begin{array}{l}\text { NS } \\
\text { NS }\end{array}$ \\
\hline 2008 & $\begin{array}{c}\text { NAA (100ppm) } \\
\text { early fruit set } \\
\text { late fruit set }\end{array}$ & $\begin{array}{l}6.56 \\
4.44\end{array}$ & $\begin{array}{l}\text { NS } \\
\text { NS }\end{array}$ & $\begin{array}{l}65.09 \\
29.74\end{array}$ & $\begin{array}{l}\text { NS } \\
\text { NS }\end{array}$ & $\begin{array}{l}8.38 \\
6.74\end{array}$ & $\begin{array}{l}\text { NS } \\
\text { NS }\end{array}$ & $\begin{array}{l}24.18 \\
22.17\end{array}$ & $\begin{array}{l}\text { NS } \\
\text { NS }\end{array}$ \\
\hline
\end{tabular}

${ }^{\mathrm{z}}$ Mean separations within column for each year by Dunnett's $t$ tests, with NS as nonsignificant at $P=0.05$. 
Table 4. The effect of 2,4-D applied at early or late fruit set on the number of longan fruit per inflorescence, fruit mass per inflorescence, fruit mass, and fruit diameter.

\begin{tabular}{|c|c|c|c|c|c|c|c|c|c|}
\hline Year & Treatment & $\begin{array}{c}\text { Fruit per } \\
\text { inflorescence } \\
\text { (no.) }\end{array}$ & $t$ tests $^{\mathrm{z}}$ & $\begin{array}{l}\text { Fruit mass per } \\
\text { inflorescence } \\
(\mathrm{g})\end{array}$ & $t$ tests & $\begin{array}{l}\text { Fruit mass } \\
(\mathrm{g})\end{array}$ & $t$ tests & $\begin{array}{l}\text { Fruit diameter } \\
(\mathrm{mm})\end{array}$ & $\begin{array}{c}t \\
\text { tests } \\
\end{array}$ \\
\hline 2007 & Untreated control & 9.88 & & 40.34 & & 4.13 & & 16.90 & \\
\hline \multirow[t]{3}{*}{2007} & 2,4-D (5ppm) & & & & & & & & \\
\hline & early fruit set & 17.24 & NS & 66.96 & NS & 4.10 & NS & 16.99 & NS \\
\hline & late fruit set & 10.92 & NS & 44.74 & NS & 4.11 & NS & 17.49 & NS \\
\hline \multirow[t]{3}{*}{2007} & 2,4-D (25ppm) & & & & & & & & \\
\hline & early fruit set & 10.52 & NS & 43.40 & NS & 4.17 & NS & 17.12 & NS \\
\hline & late fruit set & 26.22 & $*$ & 116.44 & $*$ & 4.06 & NS & 18.50 & $*$ \\
\hline \multirow[t]{3}{*}{2007} & 2,4-D (45ppm) & & & & & & & & \\
\hline & early fruit set & 13.59 & NS & 51.39 & NS & 3.85 & NS & 16.40 & NS \\
\hline & late fruit set & 12.88 & NS & 51.10 & NS & 4.04 & NS & 16.57 & NS \\
\hline 2008 & Untreated control & 8.43 & & 54.33 & & 6.51 & & 21.03 & \\
\hline \multirow[t]{3}{*}{2008} & $2,4-\mathrm{D}(5 \mathrm{ppm})$ & & & & & & & & \\
\hline & early fruit set & 6.05 & NS & 62.75 & NS & 5.29 & NS & 21.32 & NS \\
\hline & late fruit set & 5.67 & NS & 39.06 & NS & 6.92 & NS & 22.44 & NS \\
\hline \multirow[t]{3}{*}{2008} & 2,4-D (25ppm) & & & & & & & & \\
\hline & early fruit set & 5.67 & NS & 25.95 & NS & 7.69 & NS & 20.72 & NS \\
\hline & late fruit set & 10.78 & NS & 73.71 & NS & 7.02 & NS & 20.25 & NS \\
\hline \multirow[t]{3}{*}{2008} & 2,4-D (45ppm) & & & & & & & & \\
\hline & early fruit set & 7.75 & NS & 73.71 & NS & 5.75 & NS & 23.44 & NS \\
\hline & late fruit set & 5.58 & NS & 38.51 & NS & 6.00 & NS & 22.49 & NS \\
\hline
\end{tabular}

${ }^{\mathrm{z}}$ Mean separations within column for each year by Dunnett's $t$ tests, with NS, * as nonsignificant or significant at $P \leq 0.05$,

respectively. 
The trees appeared to be alternate bearing, with 2007 being an on- crop year and 2008 being an off-crop year. Fruit number and mass per inflorescence were significantly higher in 2007 than in 2008 ( $P \leq 0.001$ and 0.01 , respectively). Individual fruit mass and diameter were significantly smaller in 2007 than in $2008(P \leq 0.001)$.

During 2008, the 75 study trees had only $9.2 \pm 0.9$ inflorescences per tree. Of the 86 inflorescences monitored during the growing season, $23 \%$ set no fruit. Of those that retained fruit to harvest, three patterns of fruit abscission could be detected: (1) fruit number was largely unchanged through early and late fruit set (20 or 100 ppm NAA at late fruit set) (2) abscission continued through late fruit set (untreated control, girdling at early or late fruit set, $20 \mathrm{ppm}$ NAA at early fruit set, $60 \mathrm{ppm}$ NAA at early or late fruit set, or $5 \mathrm{ppm}$ 2,4-D at late fruit set) or (3) fruit set increased during late fruit set (5 ppm 2,4-D at early fruit set, 25 or 45 ppm 2,4-D at early or late fruit set, or 100 ppm NAA at early fruit set) (Fig. 3).

Diameter increased linearly over time at a rate of $0.12 \mathrm{~mm} \cdot \mathrm{d}^{-1}$ (measured in 2008 only), though treatments did not appear to have an effect on the rate at which fruit diameter increased (Fig. 4). At early fruit set, fruit were approximately $3 \mathrm{~mm}$ in diameter. At late fruit set, prior to the second treatment applications, fruit diameters had nearly doubled to approximately $7 \mathrm{~mm}$. Fruit diameter continued to increased rapidly, with fruit diameters reaching approximately $20 \mathrm{~mm}$ by November. 


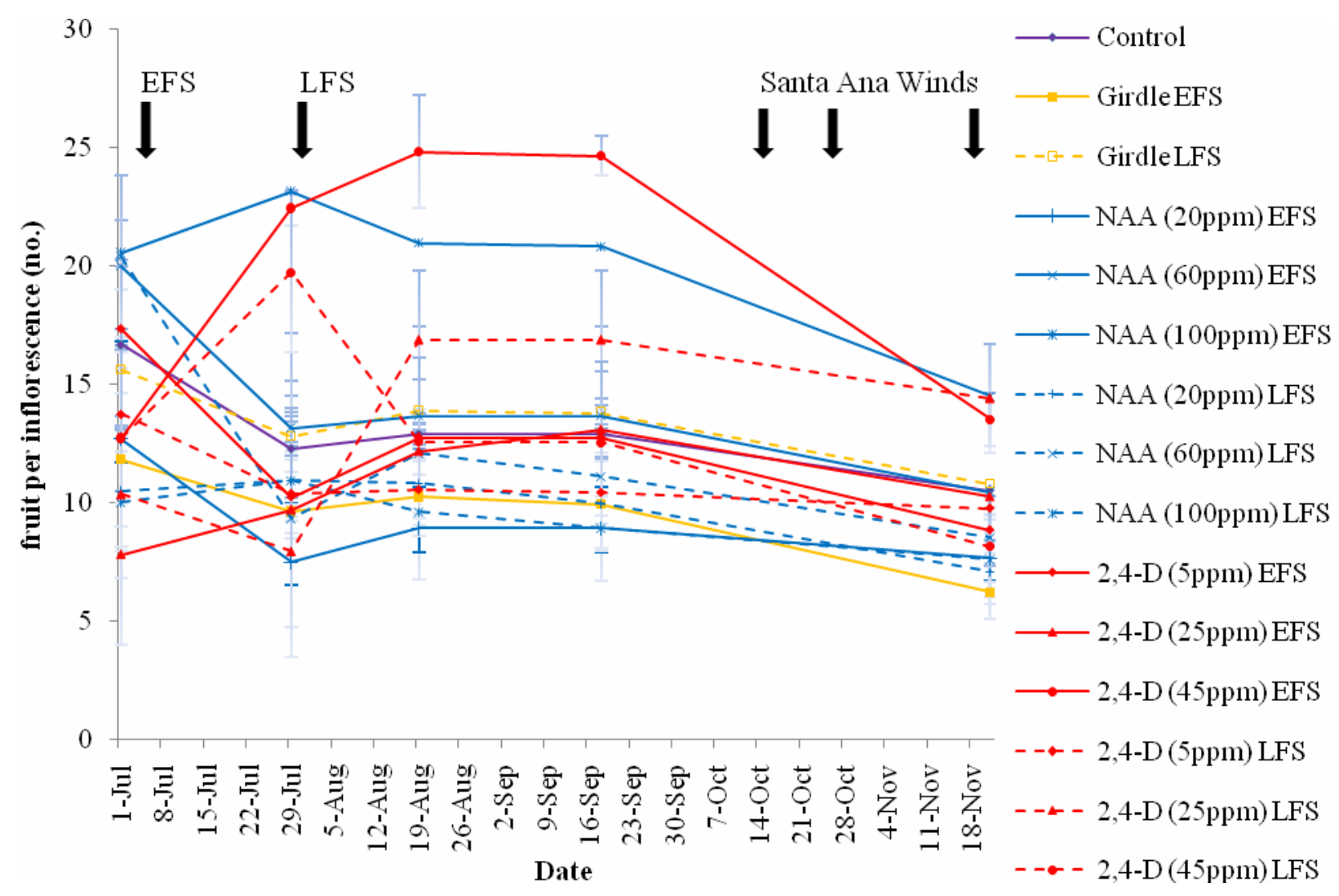

Fig. 3. Number of fruit per inflorescence during the 2008 growing season, including early fruit set (EFS), late fruit set (LFS), and during the Santa Ana winds. 


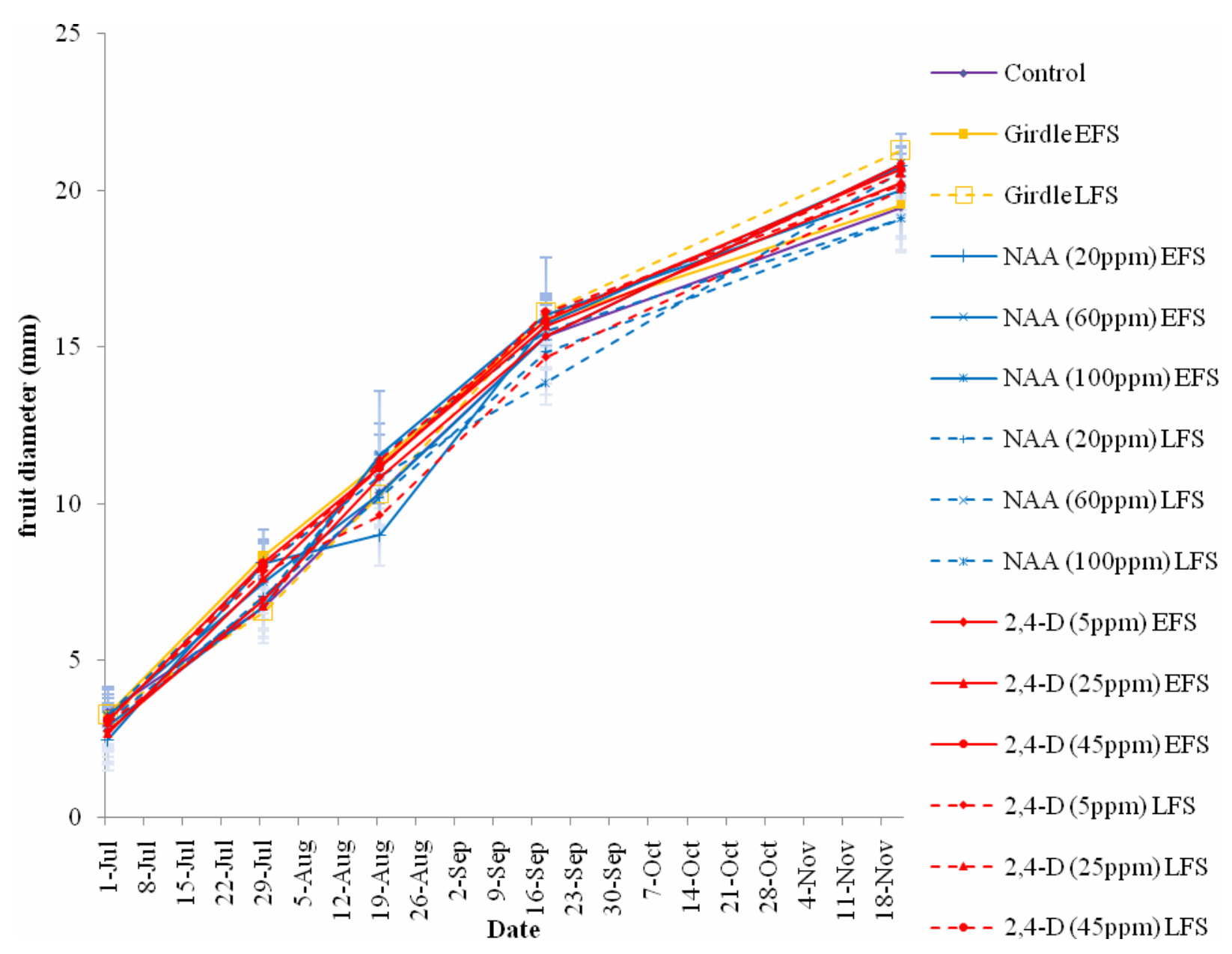

Fig. 4. Longan fruit diameter during the 2008 growing season. 
After late fruit set, few fruit abscised from any study trees until autumn (Fig. 3). Conditions characteristic of Santa Ana winds occurred in October, November, and December of both study years. In October 2007 , maximum air temperatures often reached 26 to $37{ }^{\circ} \mathrm{C}$, with a continuous $61 \mathrm{~h}$ period of 7 to $25 \mathrm{~m} \cdot \mathrm{s}^{-1}$ wind gusts. In November and December 2007, there were two $9 \mathrm{~h}$ periods of wind gusts of 10 to $35 \mathrm{~m} \cdot \mathrm{s}^{-1}$. Additionally, three squalls ranging from 49 to $67 \mathrm{~m} \cdot \mathrm{s}^{-1}$ were recorded between 28 Nov and 5 Dec 2007. Number of fruit per inflorescence decreased by $54 \% \pm 0.16 \%$ on monitored control trees between 17 Sept. 2007 and 7 Dec. 2007. Santa Ana conditions also occurred in 2008. In 2007 and 2008, average RH was below normal (19\% and $24 \%$, respectively) during these periods. In October 2008, wind gusts ranging from 8.9 to $21 \mathrm{~m} \cdot \mathrm{s}^{-}$ ${ }^{1}$ took place over an 11 and $16 \mathrm{~h}$ period with maximum air temperatures ranging from 23 to 34 ${ }^{\circ} \mathrm{C}$. Five days with Santa Ana wind gusts of 8 to $21 \mathrm{~m} \cdot \mathrm{s}^{-1}$ occurred in November and December 2008. Fruit loss occurred during these periods (Fig. 3), though there was no significant difference in percent fruit loss between treated trees and untreated controls $(P=0.05)$. Orchard visits confirmed that fruit loss occurred during these periods of Santa Ana winds.

Leaf macronutrient and micronutrient concentrations from treated trees were not significantly different from those of untreated control trees in either study year (Table 5 and 6). However, leaf nutrient concentrations differed significantly between the two study years (Tables 5 and 6). Leaf nitrogen $(\mathrm{N})$ concentrations were higher in 2007 than in 2008, whereas leaf nutrient concentrations of phosphorus $(\mathrm{P})$, potassium $(\mathrm{K})$, calcium $(\mathrm{Ca})$, copper $(\mathrm{Cu})$, boron $(\mathrm{B})$, zinc (Zn), and iron (Fe) were higher in 2008 than in 2007. 
In 2008 , treatments did not result in significant differences in fruit nutrient content as compared to untreated controls (Tables 7 and 8). Due to the pooling of fruit harvested in 2007, no statistical comparisons of fruit nutrient content were possible between treatments in 2007 (data provided in Appendix Tables A1 and A2). However, it appears that fruit $\mathrm{K}$ and $\mathrm{Ca}$ levels were much higher in 2008 than in 2007. 
Table 5. Longan leaf macronutrient content in 2007 and 2008.

\begin{tabular}{|c|c|c|c|c|c|c|c|c|c|c|}
\hline \multirow[b]{2}{*}{ Treatment } & \multicolumn{2}{|c|}{$\underline{\mathrm{N}(\%)}$} & \multicolumn{2}{|c|}{$\underline{\mathrm{P}(\%)}$} & \multicolumn{2}{|c|}{$\underline{\mathrm{K}(\%)}$} & \multicolumn{2}{|c|}{$\mathrm{Ca}(\%)$} & \multicolumn{2}{|c|}{$\underline{\operatorname{Mg}(\%)}$} \\
\hline & 2007 & 2008 & 2007 & 2008 & 2007 & 2008 & 2007 & 2008 & 2007 & 2008 \\
\hline $\begin{array}{l}\text { Untreated } \\
\text { Control }\end{array}$ & 2.0 & 1.9 & 0.1 & 0.2 & 0.5 & 0.5 & 3.2 & 3.5 & 0.3 & 0.2 \\
\hline $\begin{array}{l}\text { Girdle } \\
\text { early fruit set }\end{array}$ & 2.1 & 1.9 & 0.1 & 0.2 & 0.5 & 0.7 & 3.0 & 3.0 & 0.2 & 0.2 \\
\hline $\begin{array}{l}\text { Girdle } \\
\text { late fruit set }\end{array}$ & $-{ }^{z}$ & 1.8 & - & 0.2 & - & 0.6 & - & 3.3 & - & 0.2 \\
\hline $\begin{array}{l}\text { NAA (20 ppm) } \\
\text { early fruit set }\end{array}$ & 2.0 & 2.0 & 0.2 & 0.2 & 0.5 & 0.6 & 2.5 & 3.3 & 0.2 & 0.2 \\
\hline $\begin{array}{l}\text { NAA }(60 \mathrm{ppm}) \\
\text { early fruit set }\end{array}$ & 2.1 & 1.8 & 0.2 & 0.2 & 0.5 & 0.6 & 2.9 & 3.4 & 0.2 & 0.2 \\
\hline $\begin{array}{l}\text { NAA (100 ppm) } \\
\text { early fruit set }\end{array}$ & 2.0 & 2.0 & 0.2 & 0.2 & 0.5 & 0.6 & 3.2 & 3.4 & 0.2 & 0.2 \\
\hline $\begin{array}{l}\text { NAA }(20 \mathrm{ppm}) \\
\text { late fruit set }\end{array}$ & 2.1 & 1.9 & 0.2 & 0.2 & 0.6 & 0.5 & 2.8 & 3.4 & 0.2 & 0.2 \\
\hline $\begin{array}{l}\text { NAA ( } 60 \mathrm{ppm}) \\
\text { late fruit set }\end{array}$ & 2.0 & 2.0 & 0.2 & 0.2 & 0.4 & 0.6 & 3.3 & 3.1 & 0.3 & 0.2 \\
\hline $\begin{array}{l}\text { NAA }(100 \mathrm{ppm}) \\
\text { late fruit set }\end{array}$ & 1.9 & 2.0 & 0.1 & 0.2 & 0.4 & 0.6 & 3.3 & 3.4 & 0.3 & 0.2 \\
\hline $\begin{array}{l}2,4-\mathrm{D}(5 \mathrm{ppm}) \\
\text { early fruit set }\end{array}$ & 1.9 & 1.9 & 0.2 & 0.2 & 0.5 & 0.6 & 3.1 & 3.7 & 0.2 & 0.3 \\
\hline $\begin{array}{l}2,4-\mathrm{D}(25 \mathrm{ppm}) \\
\text { early fruit set }\end{array}$ & 1.9 & 2.1 & 0.2 & 0.2 & 0.4 & 0.6 & 2.9 & 3.4 & 0.2 & 0.2 \\
\hline $\begin{array}{l}2,4-\mathrm{D}(45 \mathrm{ppm}) \\
\text { early fruit set }\end{array}$ & 1.8 & 1.5 & 0.1 & 0.2 & 0.5 & 0.0 & 3.0 & 3.3 & 0.2 & 0.2 \\
\hline $\begin{array}{l}2,4-\mathrm{D}(5 \mathrm{ppm}) \\
\text { late fruit set }\end{array}$ & 2.0 & 1.9 & 0.2 & 0.2 & 0.5 & 0.6 & 3.1 & 3.5 & 0.2 & 0.3 \\
\hline $\begin{array}{l}\text { 2,4-D (25 ppm) } \\
\text { late fruit set }\end{array}$ & 1.9 & 1.8 & 0.1 & 0.2 & 0.4 & 0.5 & 3.2 & 4.1 & 0.2 & 0.3 \\
\hline $\begin{array}{l}\text { 2,4-D (45 ppm) } \\
\text { late fruit set }\end{array}$ & 2.0 & 1.8 & 0.2 & 0.2 & 0.5 & 0.4 & 3.1 & 3.9 & 0.2 & 0.3 \\
\hline$P^{y}$ & & & & & & & & & & \\
\hline
\end{tabular}

${ }^{z}$ The 2007 data is not available for the girdling treatment applied at late fruit set.

${ }^{\mathrm{y}}$ Probability value for paired $t$ test comparisons of yearly means with NS as not significant and $* * * *$ as significant at $P \leq 0.001$ or 0.05 , respectively. 
Table 6. Longan leaf micronutrient content in 2007 and 2008.

\begin{tabular}{|c|c|c|c|c|c|c|c|c|c|c|}
\hline \multirow[b]{2}{*}{ Treatment } & \multicolumn{2}{|c|}{$\underline{\mathrm{Zn}}(\mathrm{ppm})$} & \multicolumn{2}{|c|}{$\underline{\mathrm{Mn}(\mathrm{ppm})}$} & \multicolumn{2}{|c|}{$\underline{\mathrm{Fe}(\mathrm{ppm})}$} & \multicolumn{2}{|c|}{$\underline{\mathrm{Cu}(\mathrm{ppm})}$} & \multicolumn{2}{|c|}{$\underline{\mathrm{B}(\mathrm{ppm})}$} \\
\hline & 2007 & 2008 & 2007 & 2008 & 2007 & 2008 & 2007 & 2008 & 2007 & 2008 \\
\hline $\begin{array}{l}\text { Untreated } \\
\text { Control }\end{array}$ & 10.8 & 13.4 & 41.4 & 45.2 & 88.8 & 128.0 & 2.8 & 4.4 & 184.0 & 220.8 \\
\hline $\begin{array}{l}\text { Girdle } \\
\text { early fruit set }\end{array}$ & 10.6 & 13.2 & 40.0 & 37.0 & 75.4 & 107.6 & 3.4 & 4.4 & 176.2 & 187.4 \\
\hline $\begin{array}{l}\text { Girdle } \\
\text { late fruit set }\end{array}$ & $-{ }^{z}$ & 13.4 & - & 36.2 & - & 118.8 & - & 3.4 & - & 209.2 \\
\hline $\begin{array}{l}\text { NAA (20 ppm) } \\
\text { early fruit set }\end{array}$ & 12.2 & 16.2 & 37.0 & 40.4 & 80.0 & 111.2 & 3.8 & 4.4 & 162.4 & 182.2 \\
\hline $\begin{array}{l}\text { NAA ( } 60 \mathrm{ppm}) \\
\text { early fruit set }\end{array}$ & 12.2 & 17.0 & 43.6 & 38.0 & 98.4 & 127.6 & 3.4 & 5.2 & 180.6 & 202.2 \\
\hline $\begin{array}{l}\text { NAA (100 ppm) } \\
\text { early fruit set }\end{array}$ & 13.4 & 16.2 & 40.8 & 40.8 & 81.0 & 106.0 & 3.8 & 4.8 & 185.2 & 183.0 \\
\hline $\begin{array}{l}\text { NAA }(20 \mathrm{ppm}) \\
\text { late fruit set }\end{array}$ & 12.2 & 13.8 & 36.8 & 44.4 & 69.8 & 110.4 & 3.6 & 3.8 & 176.0 & 221.0 \\
\hline $\begin{array}{l}\text { NAA }(60 \mathrm{ppm}) \\
\text { late fruit set }\end{array}$ & 10.4 & 14.8 & 46.6 & 38.8 & 79.4 & 127.6 & 3.6 & 4.6 & 180.2 & 179.0 \\
\hline $\begin{array}{l}\text { NAA }(100 \mathrm{ppm}) \\
\text { late fruit set }\end{array}$ & 9.4 & 14.8 & 43.2 & 40.4 & 80.4 & 121.4 & 2.8 & 4.0 & 188.0 & 200.6 \\
\hline $\begin{array}{l}2,4-\mathrm{D}(5 \mathrm{ppm}) \\
\text { early fruit set }\end{array}$ & 12.2 & 15.4 & 38.0 & 43.2 & 84.0 & 122.2 & 2.8 & 4.8 & 177.8 & 216.0 \\
\hline $\begin{array}{l}2,4-\mathrm{D}(25 \mathrm{ppm}) \\
\text { early fruit set }\end{array}$ & 10.8 & 16.0 & 39.6 & 39.8 & 79.8 & 118.6 & 3.4 & 4.4 & 185.2 & 205.0 \\
\hline $\begin{array}{l}2,4-\mathrm{D}(45 \mathrm{ppm}) \\
\text { early fruit set }\end{array}$ & 12.4 & 13.8 & 36.8 & 35.2 & 66.0 & 112.4 & 3.4 & 4.4 & 170.8 & 178.0 \\
\hline $\begin{array}{l}2,4-\mathrm{D}(5 \mathrm{ppm}) \\
\text { late fruit set }\end{array}$ & 10.4 & 14.0 & 42.2 & 44.6 & 71.6 & 142.8 & 2.8 & 4.0 & 172.6 & 220.8 \\
\hline $\begin{array}{l}2,4-\mathrm{D}(25 \mathrm{ppm}) \\
\text { late fruit set }\end{array}$ & 10.8 & 12.0 & 35.6 & 53.0 & 80.4 & 132.2 & 2.6 & 4.0 & 185.4 & 246.0 \\
\hline $\begin{array}{l}2,4-\mathrm{D}(45 \mathrm{ppm}) \\
\text { late fruit set }\end{array}$ & 12.4 & 12.6 & 41.4 & 43.6 & 92.2 & 131.4 & 3.4 & 4.0 & 187.8 & 241.0 \\
\hline$P^{y}$ & & & & & & & & & & \\
\hline
\end{tabular}

${ }^{\mathrm{z}}$ The 2007 data is not available for the girdling treatment applied at late fruit set.

${ }^{\mathrm{y}}$ Probability value for paired $t$ test comparisons of yearly means with NS as not significant and $* * *$ as significant at $P \leq 0.001$. 
Table 7. Longan fruit macronutrient content in 2008.

\begin{tabular}{|c|c|c|c|c|c|}
\hline Treatment & $\mathrm{N}\left(\mathrm{mg} \cdot 100 \mathrm{~g}^{-1}\right)$ & $\mathrm{P}\left(\mathrm{mg} \cdot 100 \mathrm{~g}^{-1}\right)$ & $\mathrm{K}\left(\mathrm{mg} \cdot 100 \mathrm{~g}^{-1}\right)$ & $\mathrm{Ca}\left(\mathrm{mg} \cdot 100 \mathrm{~g}^{-1}\right)$ & $\operatorname{Mg}\left(\mathrm{mg} \cdot 100 \mathrm{~g}^{-1}\right)$ \\
\hline $\begin{array}{l}\text { Untreated } \\
\text { Control }\end{array}$ & 1046.7 & 168.3 & 1106.7 & 688.7 & 91.7 \\
\hline $\begin{array}{l}\text { Girdle } \\
\text { early fruit set }\end{array}$ & 956.7 & 162.0 & 1043.3 & 635.3 & 85.3 \\
\hline $\begin{array}{l}\text { Girdle } \\
\text { late fruit set }\end{array}$ & 1080.0 & 165.3 & 921.7 & 820.3 & 96.3 \\
\hline $\begin{array}{l}\text { NAA (20ppm) } \\
\text { early fruit Sset }\end{array}$ & 1020.8 & 174.1 & 1071.2 & 548.7 & 87.0 \\
\hline $\begin{array}{l}\text { NAA (60ppm) } \\
\text { early fruit set }\end{array}$ & 1220.0 & 179.3 & 1136.7 & 730.0 & 97.3 \\
\hline $\begin{array}{l}\text { NAA (100ppm) } \\
\text { early fruit set }\end{array}$ & 1055.1 & 157.8 & 1022.2 & 681.4 & 85.1 \\
\hline $\begin{array}{l}\text { NAA (20ppm) } \\
\text { late fruit set }\end{array}$ & 937.2 & 155.7 & 981.3 & 592.9 & 82.0 \\
\hline $\begin{array}{l}\text { NAA }(60 p p m) \\
\text { late fruit set }\end{array}$ & 1060.0 & 159.7 & 974.3 & 693.0 & 91.7 \\
\hline $\begin{array}{l}\text { NAA (100ppm) } \\
\text { late fruit set }\end{array}$ & 1073.3 & 157.3 & 937.0 & 775.0 & 94.7 \\
\hline $\begin{array}{l}2,4-\mathrm{D}(5 \mathrm{ppm}) \\
\text { early fruit set }\end{array}$ & 937.4 & 196.0 & 1319.4 & 936.3 & 109.5 \\
\hline $\begin{array}{l}2,4-\mathrm{D}(25 \mathrm{ppm}) \\
\text { early fruit set }\end{array}$ & 1093.3 & 175.0 & 1079.3 & 691.3 & 95.0 \\
\hline $\begin{array}{l}2,4-\mathrm{D}(45 \mathrm{ppm}) \\
\text { early fruit set }\end{array}$ & 1183.1 & 176.2 & 1201.4 & 694.6 & 96.4 \\
\hline $\begin{array}{l}2,4-\mathrm{D}(5 \mathrm{ppm}) \\
\text { late fruit set }\end{array}$ & 1146.7 & 173.3 & 1078.0 & 593.3 & 87.7 \\
\hline $\begin{array}{l}2,4-\mathrm{D}(25 \mathrm{ppm}) \\
\text { late fruit set }\end{array}$ & 1070.0 & 170.7 & 1126.7 & 572.7 & 85.3 \\
\hline $\begin{array}{l}2,4-\mathrm{D}(45 \mathrm{ppm}) \\
\text { late fruit set }\end{array}$ & 1153.3 & 177.0 & 1035.0 & 662.7 & 87.3 \\
\hline
\end{tabular}


Table 8. Longan fruit micronutrient content in 2008.

\begin{tabular}{|c|c|c|c|c|c|}
\hline Treatment & $\mathrm{Zn}(\mathrm{ppm})$ & $\mathrm{Mn}(\mathrm{ppm})$ & $\mathrm{Fe}(\mathrm{ppm})$ & $\mathrm{Cu}(\mathrm{ppm})$ & B (ppm) \\
\hline $\begin{array}{l}\text { Untreated } \\
\text { Control }\end{array}$ & 1.1 & 1.0 & 2.8 & 0.8 & 3.3 \\
\hline $\begin{array}{l}\text { Girdle } \\
\text { early fruit set }\end{array}$ & 1.0 & 0.7 & 2.6 & 0.9 & 2.6 \\
\hline $\begin{array}{l}\text { Girdle } \\
\text { late fruit set }\end{array}$ & 1.1 & 1.0 & 3.1 & 1.1 & 3.1 \\
\hline $\begin{array}{l}\text { NAA (20ppm) } \\
\text { early fruit set }\end{array}$ & 1.4 & 0.9 & 3.2 & 0.8 & 3.3 \\
\hline $\begin{array}{l}\text { NAA (60ppm) } \\
\text { early fruit set }\end{array}$ & 1.2 & 0.9 & 4.1 & 0.6 & 3.5 \\
\hline $\begin{array}{l}\text { NAA (100ppm) } \\
\text { early fruit set }\end{array}$ & 1.0 & 0.8 & 3.1 & 1.1 & 3.5 \\
\hline $\begin{array}{l}\text { NAA (20ppm) } \\
\text { late fruit set }\end{array}$ & 1.0 & 0.8 & 3.9 & 0.8 & 3.2 \\
\hline $\begin{array}{l}\text { NAA }(60 \mathrm{ppm}) \\
\text { late fruit set }\end{array}$ & 1.1 & 0.9 & 3.1 & 0.7 & 3.0 \\
\hline $\begin{array}{l}\text { NAA }(100 p p m \\
\text { late fruit set }\end{array}$ & 1.0 & 0.9 & 3.2 & 0.7 & 3.0 \\
\hline $\begin{array}{l}2,4-\mathrm{D}(5 \mathrm{ppm}) \\
\text { early fruit set }\end{array}$ & 1.2 & 0.9 & 4.0 & 0.8 & 3.5 \\
\hline $\begin{array}{l}2,4-\mathrm{D}(25 \mathrm{ppm}) \\
\text { early fruit set }\end{array}$ & 1.2 & 0.9 & 6.3 & 0.7 & 3.4 \\
\hline $\begin{array}{l}2,4-\mathrm{D}(45 \mathrm{ppm}) \\
\text { early fruit set }\end{array}$ & 1.2 & 1.0 & 4.2 & 1.0 & 3.4 \\
\hline $\begin{array}{l}\text { 2,4-D }(5 \mathrm{ppm}) \\
\text { late fruit set }\end{array}$ & 1.2 & 0.8 & 3.0 & 0.7 & 3.6 \\
\hline $\begin{array}{l}2,4-\mathrm{D}(25 \mathrm{ppm}) \\
\text { late fruit set }\end{array}$ & 1.1 & 0.8 & 3.1 & 0.9 & 3.2 \\
\hline $\begin{array}{l}\text { 2,4-D (45ppm) } \\
\text { late fruit set }\end{array}$ & 1.2 & 0.9 & 3.4 & 0.8 & 3.1 \\
\hline
\end{tabular}




\section{$\underline{\text { Discussion }}$}

The PGR spray regime of $25 \mathrm{ppm}$ 2,4-D applied at late fruit set resulted in a significant increase in the mass and number of longan fruit per inflorescence without a concomitant decrease in individual fruit mass and diameter in the on-crop year. Late fruit set $25 \mathrm{ppm}$ 2,4-D was one of the only treatments, including the untreated control, to result in a numerically higher number and mass of longan fruit per inflorescence without a decrease in individual fruit mass and diameter during the off-crop year, suggesting that this treatment might also help to mitigate alternate bearing. These results are consistent with those reported by previous researchers who found that low levels of synthetic auxins applied during fruit set increase litchi yields (Prasad and Jauhari, 1963; Hoda et al., 1973; Huang, 2002). The results reported herein are the first to demonstrate the effectiveness of this horticultural technique with longan.

Treatment effectiveness appears to have been the result of increasing the number of fruit that survive from fruit set. Several PGR treatments applied at early or late fruit set improved fruit retention during early and/or late fruit set; this corresponds to the second wave of fruit abscission, when fruit that are fertilized often drop (Stern et al., 1995; Stern and Gazit, 1997; Stern and Gazit, 1999). Few fruit abscised after this period, suggesting that if fruit are maintained during early and late fruit set by PGR sprays such as 2,4-D, they are highly likely to be retained through the season.

The results of longan pruning studies suggest that there is an inverse relationship between fruit number and fruit size (Wang et al., 2003); as the number of fruit increases, fruit size typically decreases. In the study reported herein, 25 ppm 2,4-D applied at late fruit set increased fruit 
number and size as measured by both mass and width, as compared to the untreated control. This suggests that this PGR regime provides a method for substantial production increases. Additionally, the trees appear to be capable of sustained yield increases, as yields were not depressed when the same trees were treated with $25 \mathrm{ppm} 2,4-\mathrm{D}$ at late fruit set during the following off-crop year.

Further, multi-year studies would be required before such treatments could be implemented on a commercial scale. The treatments tested have the potential to be implemented commercially, as the PGR compounds and method of girdling tested are both used commercially on other fruit tree crops. Other treatments tested in this study should also be researched further, as no deleterious effects on reproductive and vegetative growth were detected in response to any PGR or girdling regimes tested. Successful treatments should be tested at multiple locations, thus adding to the body of work required for the addition of longans to commercial PGR labels.

The limited effectiveness of girdling to increase fruit set was surprising, given its successful commercial use on many fruit and vine crops (reviewed by Goren et al., 2004). Experimental uses of girdling have also been reported to increase fruit set on subtropical fruit tree crops, including mango (Nuñez-Elisea et al., 1996), macadamia (Trueman and Turnbull, 1994), and avocado (Garner, 2004). In the study described herein, girdling at early fruit set resulted in an approximately $50 \%$ increase in the number of fruit per inflorescence in an on-crop year but was one of the few treatments that resulted in a numerically lower number of fruit and fruit mass per inflorescence in an off-crop year. Further testing of this technique is warranted. 
Techniques such as PGR sprays are often employed to decrease excessive litchi fruit abscission. In contrast, longans are described as having lower fruit abscission rates than litchis (Stern, 2005) and cultural methods are, therefore, rarely employed to increase longan fruit set. However, there is a need to increase longan fruit set in California because the climate appears not to be ideal for this crop. Longans are native to warm, humid, subtropical areas and grow in forests, thus limiting tree exposure to wind. Yields and fruit sizes reported herein were smaller than those reported for subtropical growing regions, such as Australia (Winston et al., 1993) and Thailand (Huang et al., 2005). This study demonstrated that weather-induced stress substantially decreases longan yields. Santa Ana winds were associated with distinct periods of fruit drop during a period of development not typically characterized by physiological abscission of longan fruit. That fruit loss was a result of wind damage was consistent with coinciding reports by regional growers that fruit drop occurred as a result of high winds in autumn of 2007 (California Farm Bureau Federation, 2007) and 2008 (USDA, 2008c). Specifically, one grower in Camarillo reported "a significant amount of fruit drop" from lemon and avocado trees due to Santa Ana winds (California Farm Bureau Federation, 2007). These winds are common during autumn and winter in southern California (Fovel, 2007) and will, therefore, be a consistent, limiting factor to longan production in California. Until now, minimal evidence has been reported regarding the susceptibility of longans to wind, except to describe them as less susceptible to wind than litchis (Menzel et al., 2005).

Tree height and vigor appeared to be inversely proportional to distance from the Eucalyptus windbreak (Fig. 1). Windbreaks are often used to decrease wind velocity but can also have other effects on orchard climate, including reducing air and soil temperature and water content (Ujah 
and Adeoye, 1984). Eucalyptus windbreaks have been shown to decrease millet (Pennisetum typhoides Burm.) yields (Onyewotu et al., 1994). The authors demonstrated that the primary factor limiting millet yields was reduced nutrient and water availability due to the growth of Eucalyptus roots into the field. In the study reported herein, vegetative and reproductive growth of longan trees was noticeably reduced near the Eucalyptus windbreak. One possible reason for the longan trees' reduced vegetative and reproductive growth was their proximity to Eucalyptus trees. This suggests that even though protection from wind damage will be necessary for successful longan production, Eucalyptus is unlikely to be an appropriate windbreak species. Weather stations should be installed in longan orchards to ensure that windbreaks reduce wind speeds effectively and sufficiently. Proper windbreaks are also necessary to determine the extent to which high temperatures associated with October Santa Ana winds contribute to late season drop.

Another factor possibly influencing fruit set was inflorescence type. The majority of the inflorescences were determinate. Though only determinate inflorescences are described in previous longan literature, indeterminate inflorescences were observed on the study trees during both years. Fruit set of indeterminate inflorescences of fruit trees often differs from that of determinate inflorescences because new vegetative growth is developing concurrent with early fruit set (Garner, 2004).

Optimal leaf nutrient concentrations for longan have been determined in several published studies but the phenological stage at which leaves were collected and number of macro- and micronutrients varied between studies (reviewed in Menzel, 2005). In the current study, leaf 
nutrient analyses indicated that $\mathrm{P}$ and $\mathrm{Mg}$ were within suggested optimal ranges for leaves sampled 1 month before early fruit set. Nitrogen, $\mathrm{Ca}$, and $\mathrm{B}$ concentrations in the leaves were higher than optimal in both years, whereas, K, Zn, Mn, and Fe were below optimal. Currently, optimal $\mathrm{Cu}$ leaf concentrations for longan are not described in the literature, though $\mathrm{Cu}$ concentrations reported herein were only slightly below the minimal optimum of 10 to $25 \mathrm{ppm}$ reported for litchi (Huang et al., 1998; Menzel et al., 1992). Only two of the nutrients, Mn and B, had measured concentrations grossly outside of reported optimal ranges. In 2007 and 2008, Mn concentrations in the leaves were five times lower than optima reported by Chen (1997) for longan leaves collected before flowering, the same stage of development at which collections were made in this study. However, leaf Mn concentrations were within the optimal ranges described by Zhuang et al. (1995) for leaves sampled before flower initiation. Concentrations of B were higher than all reported optima by an order of magnitude. The leaf B concentrations reported herein are considered superoptimal for "normal plants" (Troeh and Thompson, 2005) and might be the result of high B soil levels (not measured) common to arid regions of California (Troeh and Thompson, 2005). Soil modification could be necessary for successful growth of longan in these regions.

Until now, there was limited published information regarding the nutrient content of longan fruit. Previous reports of longan fruit nutrient content included only a limited number of nutrients The fruit nutrient concentrations reported herein are consistent with those reported for longan fruit nutrient concentrations of P and Fe (Deng et al., 1999 and University of Florida, 2009) and K (University of Florida, 2009). This information will be important for marketing this fruit to new consumers. 


\section{Conclusion}

Applications of 25 ppm 2,4-D at late fruit set limited fruit abscission during fruit set, increased fruit number and size at harvest during the on-crop year, and appeared to limit alternate bearing. Therefore, this treatment has potential for commercial application in California as a horticultural method to improve fruit retention and final yield. Further studies to determine methods to decrease fruit drop in areas prone to high winds will also be required for successful production in most California growing regions. This study appears to be one of the first comprehensive reports available regarding longan fruit nutrient content, especially for fruit grown in California. This study adds to the body of knowledge regarding the nutrient content of longan leaves and fruit; this data will be required for the development of successful fertilization regimes for this crop in California. Additional research is recommended for all the PGR and girdling treatments tested in this study in order to assess potential economic viability, environmental impacts, and long-term effects on tree productivity and health. 


\section{References}

Bangerth, F., 2000. Abscission and thinning of young fruit and their regulation by plant hormones and bioregulators. Plant Growth Regulat., 43-59.

Batten, D.J., Lahav, E., 1994. Base temperatures for growth processes of lychee, a recurrently flushing tree, are similar, but optima differ. Australian Journal of Plant Physiology 21, 589-602.

Bruhn, C.M., 2002. Consumer Issues in Quality and Safety. In: Kader, A.A. (Ed.), Postharvest Technol. of Hort. Crops. Univ. of Calif. Agr. and Natural Resources, pp. 31-46.

Burger, W.D., 2003. Plant growth regulators: An introduction. In: Plant Growth Regulators. A study guide for agricultural pest control advisers. Univ. of Cali. Agr. and Natural Resources Publication 4047. pp. 1-10.

California Department Water Resources. 2008. California Irrigation Management Information System. 4 June 2009. http://www.cimis.water.ca.gov.

California Farm Bureau, 2007. From the Fields. 4 June 2009.

http://www.cfbf.com/fromthefields/index.cfm?AgAlertIssueID=3442.

Chadha, K.L., Rajpoot, M.S., 1969. Studies on floral biology, fruit set, and its retention and quality of some litchi varieties. Indian J. of Hort., 124-129. 
Chang, C.C., 1961. Studies on the fruit shedding of lychee. J. of Agr. Assn. of China, 43-50.

Coggins, C.W., 2003. Plant growth regulators for citrus. In: Davies, P.J. (Ed.), Plant Growth Regulators. Univ. of Cali. Agr. and Natural Resources, pp. 35-37.

Costés, 1988. Analyze architecturale et modelisation du litchi (Litchi chinensis Sonn.). Univ. of Montpellier, France, Montpellier.

Davenport, T.L., Stern, R.A., 2005. Flowering. In: Menzel, C.M., Waite, G.K. (Eds.), Litchi and Longan Botany, Production and Uses. CABI, pp. 87-105.

Deng, X.M., Han, Z.H., Li, S.H., 1999. Fruit Tree Biology. Higher Education Press, Beijing, China.

Florida Agricultural Market Research Center, 2009. Miami Dade Agricultural Land Retention Study. 4 June 2009.

http://www.agmarketing.ifas.ufl.edu/dlfiles/DadeAgLandRetentionAppendixVolumeB.pdf.

Food and Agriculture Organization (FAO), 2000. Longan Production in Asia. 4 June 2009. http://www.fao.org/docrep/003/x6908e/x6908e6900.htm.

Fovel, R, 2007. The Santa Ana Winds FAQ. 4 June 2009.

http://www.atmos.ucla.edu/ fovell/ASother/mm5/SantaAna/santa_ana_faq.html. 
Galán, S.V., Menini, U.G., 1989. Lychee Cultivation. FAO Plant Production and Protection Paper, Rome, p. 205.

Garner, L.G. 2004. Dissertation. Univ. of Calif., Riverside. Characterization and Manipulation of Flower and Fruit Abscission of 'Hass' Avocado (Persea Americana Mill.)

Gianfagna, T.J., 1990. Narural and synthetic growth regulators and their uses in horticultural and agronomic crops. In: Davis, P.J. (Ed.), Plant hormones and their role in plant growth and development. Kluwer Academic Publishers, pp. 616-619.

Goren, R., Huberman, M., Goldschmidt, E.E., 2004. Girdling: Physiological and horticultural aspects. Hort. Rev., 1-36.

Han, D.M., Wu, Z.X., Ji, Z.L., 2001. Effects of $\mathrm{SO}_{2}$ Treatment on the Overall Quality of Longan Fruits (CV. Shixia) During Cold Storage. In: Huang, H., Menzel, C.M. (Eds.), Proc. of the First Intl. Symp. of Litchi and Longan. CABI, Guangzhou, China, pp. 375-378.

Hieke, S., Menzel, C.W., Lüdders, P., 2002. Effects of light availability of leaf gas exchange and expansion in lychee (Litchi chinensis). Tree Physiol., 1249-1256.

Hoda, M.N., Syamal, N.B., Chonkar, V.S., 1973. Effect of growth substances and zinc on litchi fruit drop. Indian J. of Hort., 456-460. 
Holcroft, D.M., Lin, H., Ketsa, S., 2005. Harvesting and Storage. In: Menzel, C.M., Waite, G.K. (Eds.), Litchi and Longan Botany, Production and Uses. CABI, pp. 273-290.

Huang, H.B., 2002. Unfruitfulness of young litchi trees in relation to their peculiar root growth behavior: an overview. In: Drew, R. (Ed.), Intl. Symp. on Trop. and Subtrop. Fruits. ISHS, Cairns, Australia, pp. 737-743.

Huang, W.T., Huang Y.M., Hsiang, W.M., Chang, M.H., Lin, M.L., Wang, C.H. and Wu, W.L., 1998. Nutrition studies on lychee (Litchi chinensis Sonn.) orchards in central Taiwan. J. of Agr. Res. of China 47, 388-407.

Huang, X.M., Subhadrabandhu, S., Mitra, S.K., Ben-Arie, R., Stern, R.A., 2005. Orgin, History, Production and Processing. In: Menzel, C.M., Waite, G.K. (Eds.), Litchi and Longan Botany, Production and Uses. CABI, pp. 1-21.

Ji, Z.L., Liang, L.F., Liu, J.L., Wang, G.T., 1992. Studies on the changes of endogenous hormone contents in litchi (Litchi chinensis Sonn.) fruits during development. J. of South China Agr. Univ., 93-98.

Joubert, A.J., 1986. Litchi. In: Monselise, S.P. (Ed.), Hdbk. of Fruit Set and Dev. CRC Press, Boca Raton, pp. 233-246. 
Ke, G.W., Wang, C.C., Tang, Z.F., 1994. Palynological studies on the origin of longan cultivation. In: H. Huang, C.M. (Ed.), Proc. of First Intl. Symp. on Longan and Lychee. ISHS, Guangzhou, China, pp. 323-328.

Li, C., Xiao, Y., 2001. Girdling increases yield of 'Nuomici' litchi. In: Huang, H., Menzel, C.W. (Eds.), Proc. of the First Intl. Symp. of Litchi and Longan. ISHS, Guangzhou, China, pp. 233235.

Lin, H.T., Chen, S.J., Hong, Q.Z., 2001. A Study of the Shelf-Life of Cold Stored Longan Fruit. In: Huang, H., Menzel, C.W. (Eds.), Proc. of the First Intl. Symp. of Litchi and Longan. ISHS, Guangzhou, China, pp. 353-357.

Lomax, T.L., Munday, G.K., Rubery, P.H., 1995. Auxin transport. In: Davies, P.J. (Ed.), Plant Hormones: Physiol., Biochem. and Mol. Biol., Boston, pp. 509-530.

Menzel, C.W., 2004. Lychee Production in the Asia-Pacific Region. In: Papademetriou, M.k., Dent, F.J. (Eds.), Lychee Production in Australia. RAP Publ., Bangkok, Thailand,

Menzel, C.W., 2005. Photosynthesis and productivity. In: Menzel, C.M., Waite, G.K. (Eds.), Litchi and Longan Botany, Production and Uses. CABI, pp. 153-179.

Menzel, C. W., Carseldine, M.L., Haydon, G.F. and Simpson, D.R. 1992. A review of existing and proposed new leaf nutrient standards for lychee. Scientia Horticulturae 49, 33-53. 
Menzel, C.W., Huang, X., Chengming, L., 2005. Cultivars and plant improvement. In: Menzel, C.M., Waite, G.K. (Eds.), Litchi and Longan Botany, Production and Uses. CABI, Wallinford, pp. 59-86.

Menzel, C.W., McConchie, C., 1997. Lychee and longan. In: Hyde, K. (Ed.), The New Rural Industries - A Handbook for Farmers and Investors. Research and Development Corporation (RIRDC), Canberra, Australia, pp. 288-295.

Menzel, C.W., Paxton, B.F., 1985. The effects of temperature on growth and dry matter production of lychee seedlings. Scientia Hort., 17-23.

Menzel, C.W., Simpson, D.R., 1988. Effect of temperature on growth and flowering of litchi (Litchi chinensis Sonn.) cultivars. J. of Hort. Sci., 349-360.

Menzel, C.W., Watson, B.J., Simpson, D.R., 1989. Longan: a place in Queensland's horticulture? Queensland Agr. J., 251-265.

Morton, J.F., 1987. Lychee. In: Morton, J.F. (Ed.), Creative Resources System, Inc., Winterville, NC, Fruits of Warm Climates. pp.249-259. 4 June 2009.

Mustard, M.J., Lui, S., Nelson, R.O., 1953. Observations of floral biology and fruit setting in lychee varieties. Proc. of the Fla. State Soc. 66, 212-220. 
Mustard, M.J., Lui, S., Nelson, R.O., Goldweber, S. 1956. Exploratory study dealing with the effect of growth regulators and other factors on the lychee. Proc. of the Fla. Lychee Growers' Assn. 3, 33-38.

Nakata, S., 1956. Lychee flowering and girdling. Hawaii Farm Sci., 4-5.

Nakata, S., Watanabe, Y., 1966. Effects of photoperiod, and night temperature on flowering of Litchi Chinensis. Botanical Gaz., 146-152.

National Oceanic Atmospheric Administration. 2009 National Climatic Data Center. 4 June 2009. http://www.ncdc.noaa.gov/oa/ncde.html>.

Nicholls, B.G., 2001. A perspective of Australian longan industry. In: Huang, H., Menzel, C.W. (Eds.), Proc. of the First Intl. Symp. of Litchi and Longan. ISHS, Guangzhou, China, pp. 45-47.

Nuñez-Elisea, R., Davenport, T.L., Caldeira, M.L., 1996. Control of bud morphogenesis in mango (Mangifera indica L.) by girdling, defoliation and temperature modification. J. Hort. Sci., 25-39.

Office of Agricultural Economics, 2009. Agr. Stat. of Thailand. Table 61, Longan. 4 June 2009. http://www.oae.go.th/statistic/yearbook50/section55/sec55table61.pdf. 
Onyewotu, L.O.Z., Ogigirigib, M.A., Stigterc, C.J., 1994. A study of competitive effects between a Eucalyptus camaldulensis shelterbelt and an adjacent millet (Pennisetum typhoides) crop. Agr., Ecosystem and Environ., 51, pp.281-286.

Ozga, J.A., Reinecke, D.M., 2003. Hormonal interactions in fruit development. J. Plant Growth Regulat., 73-81.

Prasad, A., Jauhari, O.S., 1963. Effect of 2,4,5-trichlorophenoxyacetic and alpha naphthaleneacetic acids on 'drop stop' and size of litchi fruits. Madras Agr. J., 28-29.

Robbertse, H.F., Fivaz, J., Menzel, C.M., 1995. A Reevaluation of Tree Model, Inflorescence Morphology, and Sex Ratio in Lychee (Litchi chinensis Sonn.). J. of the Amer. Soc. for Hort. Sci., 914-920.

Smith, J., 1979. EPA halts most use of herbicide 2,4,5-T. Science. 203, 1090-1091.

Southwick, S.M., 2003. Plant growth regulators for fruit and nut crops. In: Plant growth regulators. A study guide for agricultural pest control advisers. Univ. of Cali. Agr. and Natural Resources Publication 4047. pp. 15-21.

Stern, R.A., 1992. Elucidation of the factors affecting litchi production in Israel, and the development of methods to improve its yield. PhD. Thesis, Faculty of Agr., Hebrew Univ., Rehovot, Israel. 
Stern, R.A., 2005. Fruit Set, Development and Maturation: Longan. In: Menzel, C.M., Waite, G.K. (Eds.), Litchi and Longan Botany, Production and Uses. CABI, pp. 138-140.

Stern, R.A., Gazit, S., 1997. Effect of 3,5,6-trichloro-2-pyridyl-oxyacetic acid on fruitlet abscission and yield of 'Mauritius' litchi (Litchi chinensis Sonn.). J. of Hort. Sci., 659-663.

Stern, R.A., Gazit, S., 1998. Pollen viability in lychee. J. of the Amer. Soc. for Hort. Sci., 41-46.

Stern, R.A., Gazit, S., 1999. The synthetic auxin 3,5,6-TPA reduces fruit drop and increases yield in 'Kaimana' litchi. J. Hort. Sci. Biotechnol., 203-205.

Stern, R.A., Kigel, J., Tomer, E., Gazit, S., 1995. 'Mauritius' lychee fruit development and reduced abscission after treatment with the auxin 2,4,5-TP. J. of the Amer. Soc. for Hort. Sci. 120.

Stern, R.A., Stern, D., Miller, H., Xu, H., Gazit, S., 2001. The effect of the synthetic auxins 2,4,5-TPA and 3,5,6-TPA on yield and fruit size of young 'Fei Zi Xiao' and 'Hei Ye' litchi trees in Guangxi Province, China. Proc. of the First Intl. Symp. of Litchi and Longan, Guangzhou, China, pp. 285-288.

Stewart, W.S., Hield, H.D., 1949. Effect of 2,4-dichlorophenoxyacetic and 2,4,5trichlorophenoxyacetic acids on fruit drop, fruit production, and leaf drop of lemon trees. Proc. Amer. Soc. Hort. Sci., 163-171. 
Subhadrabandhu, S., Stern, R.A., 2005. Taxonomy, botany and plant development. In: Menzel, C.M., Waite, G.K. (Eds.), Litchi and Longan Botany, Production and Uses. CABI, pp. 25-32.

Subhadrabandhu, S., Yapwattanphun, C., 2001. Regulation off-season flowering of longan in Thailand. In: Huang, H., Menzel, C.W. (Eds.), Proc. of the First Intl. Symp. of Litchi and Longan. ISHS, Guangzhou, China, pp. 193-196.

Thompson, J.F., 2002. Storage systems. In: Kader, A.A. (Ed.), Postharvest Technol. of Hort. Crops. Univ. of Cali. Agr. and Natural Resources, pp. 113-126.

Tindall, H.D., 1994. Sapindaceous fruits: botany and horticulture. Hort. Rev., pp. 143-195.

Troeh, F.R., Thompson, L.M., 2005. The micronurients. In: Soil and Soil Fertility. Blackwell Publishing, Chichester, England, pp. 283-304.

Trueman, S.J., Turnbull, C.G.N., 1994. Fruit set, abscission and dry matter accumulation on girdled branches of macadamia. Ann. Bot. 74: 667-674.

Ujah, J., Adeoye, K.B., 1984. Effects of shelterbelts in the Sudan savanna zone of Nigeria on microclimate and yield of millet. Agr. and Forest Meteorol., 99-107.

United States Department Agriculture, 2008a. "Hawaii Specialty Fruits." 4 June 2009. 
http://www.nass.usda.gov/Statistics_by_State/Hawaii/Publications/Fruits_and_Nuts/tropfrt.pdf.

United States Department Agriculture, 2008b. Tropical Fruit in China. 4 June 2009. http://www.fas.usda.gov/gainfiles/200805/146294773.pdf.

United States Department Agriculture, 2008c. Fruit and Tree Nuts Outlook. 4 June 2009. http://www.ers.usda.gov/Publications/fts/2007/2011Nov/FTS2330.pdf.

University of Florida, (IFAS), 2009. Longan Growing in the Fla. Home Landscape. 4 June 2009. http://edis.ifas.ufl.edu/MG049

University of Hawaii at Manoa, 2002. Farmer's Bookshelf, Lychee. 4 June 2009. http://www.ctahr.hawaii.edu/fb/lychee/lychee.htm\#top.

Ventura County Cooperative Extension, 2009. Univ. of Cali. Agr. and Natural Resources. "Longan". 4 June 2009. http://ceventura.ucdavis.edu/Agriculture265/Longan.htm.

Wang, H.C., Haung, J.G., Li, J.G., Pan, X.W., 2003. Effects of panicle thinning and applicationn of growth regulators on fruit size and quality of 'Shixia' longan. In: Chomchalow, N., Sukhvibul, N. (Ed.), The Second International Symposium on Lychee, Longan, Rambutan and other Sapindaceae Plants, Chiang Mai, Thailand. 
Winston, E.C., O'Farrell, P.J., Young, K.E., 1993. The yield and fruit quality of 18 longan. J. of the Amer. Pomol. Soc. 47. 3, 6.

Wu, D.Q., Qiu, J.D., Zhang, H.L., Lou, X.Z., 2000. A study on flowering promotion by ringing longan (Dimocarpus longan Lour.). Scientia Agr. Sinicia, 40-43.

Xiang, X., Zhang, Z.W., Qui, Y.P., Yuan, P.Y., Wang, B.Q., 1994. A study of fruit set physiology in relation to endogenous hormones in litchi (Litchi chinensis Sonn.) fruits. Acta Hort. Sinica, China, pp. 1-6.

$\mathrm{Xu}$, E., 1962. Studies on growth regulator sprays to reduce fruit drop in litchi. Postgraduate thesis, South China Agr. College, Guangzhou, China.

Young, T.W., 1957. Lychee. Annu. Rpt of Flag. Agr. Expt. Sta., Gainesville, Fla, pp. 353-354.

Yuan, R.C., Huang, H.B., 1988. Litchi fruit abscission: its patterns, effect of shading and relation to endogenous abscisic acid. Scientia Hort.

Yuan, R.C., Huang, H.B., 1991. Effect of NAA plus nucleotides on fruit set of lychee. Yrbk. of the Austral. Lychee Growers' Assoc., 46-50. 
Zee, T.P., Chan, H.T., Yen, C.R., 1998. Lychee, longan, rambutan and pulasan. In: Shaw, P.E., Chan, H.T., Nagy, S. (Eds.), Trop. and Subtrop. Fruits. AgScience, Inc., Auburndale, pp. 290328.

Zhou, B.Y., Li, J.G., Huang, X.M., Zhou. X.J., 1999. Changes of ZRs, GA and IAA content during fruit development of longan. J. of South China Agr. Univ., 50-53.

Zhuang, Y.M., Wang, R.J., Xie, Z.N., Xu, W.B., 1995 Optimum range of mineral element contents in the leaves of Shuizhang longan. J. of Fujian Agr. Univ. 24, 281-286. 


\section{Appendix A: 2007 Fruit Nutrient Content}

Table A1. Fruit macronutrient content at 2007 harvest.

\begin{tabular}{lccccc}
\hline \hline Treatment & $\mathrm{N}\left(\mathrm{mg} \cdot 100 \mathrm{~g}^{-1}\right)$ & $\mathrm{P}\left(\mathrm{mg} \cdot 100 \mathrm{~g}^{-1}\right)$ & $\mathrm{K}\left(\mathrm{mg} \cdot 100 \mathrm{~g}^{-1}\right)$ & $\mathrm{Ca}\left(\mathrm{mg} \cdot 100 \mathrm{~g}^{-1}\right)$ & $\mathrm{Mg}\left(\mathrm{mg} \cdot 100 \mathrm{~g}^{-1}\right)$ \\
\hline $\begin{array}{l}\text { Untreated } \\
\text { Control }\end{array}$ & 1248 & 175.0 & 677.4 & 419.4 & 81.4 \\
Girdle & 1158 & 166.4 & 663.2 & 433.2 & 82.6 \\
NAA & 1174 & 170.8 & 654.6 & 445.2 & 81.2 \\
2,4-D & 1340 & 185.0 & 772.2 & 386.0 & 86.6 \\
\hline
\end{tabular}

Table A2. Fruit micronutrient content at 2007 harvest.

\begin{tabular}{lllllc}
\hline \hline Treatment & $\mathrm{Zn}(\mathrm{ppm})$ & $\mathrm{Mn}(\mathrm{ppm})$ & $\mathrm{Fe}(\mathrm{ppm})$ & $\mathrm{Cu}(\mathrm{ppm})$ & $\mathrm{B}(\mathrm{ppm})$ \\
\hline $\begin{array}{l}\text { Untreated } \\
\text { Control }\end{array}$ & 1.10 & 0.82 & 2.35 & 0.44 & 2.58 \\
Girdle & 1.12 & 0.94 & 2.74 & 0.52 & 2.52 \\
NAA & 1.08 & 0.88 & 2.48 & 0.56 & 2.63 \\
2,4-D & 1.20 & 1.02 & 3.30 & 0.56 & 3.10 \\
\hline
\end{tabular}

